\title{
PENERAPAN AKUNTANSI LINGKUNGAN BERDASARKAN TRIPLE BOTTOM LINE PADA RSUD H. M. DJAFAR HARUN KABUPATEN KOLAKA UTARA
}

\author{
Evi Nurhidayat \\ Universitas Muslim Indonesia Makassar \\ Email: evinurhidayat@gmail.com \\ Asriani Junaid \\ Universitas Muslim Indonesia Makassar \\ Email: asrianijunaid@gmail.com \\ Jeni Kamase \\ Universitas Muslim Indonesia Makassar \\ Email: jenikamase@gmail.com
}

\begin{abstract}
This study aims to determine the application of environmental accounting in terms of the Triple Bottom Line concept at H. M. Djafar Harun District Hospital in North Kolaka Regency. This research uses descriptive qualitative research. Data collection uses primary and secondary data with in-depth interviews with informants who are in the area of H. M. Djafar Harun District Hospital in North Kolaka Regency. The results showed that the environmental accounting carried out by H. M. Djafar Harun District Hospital in North Kolaka Regency generally met the triple bottom line concept which included three main elements, namely profit, people and planet. Economic responsibility (profit) can be seen in health products produced from other health service activities that have been developed. Environmental responsibility (planet) can be seen from CSR programs in the environmental field that are actually carried out to save and preserve the environment such as planting trees and landfills. Social responsibility (people) is actually implemented through CSR activities in the provision of health facilities. This means that the principle of sustainable development which states that people and the environment are an integral part of the wheels of business turnover has been done by H. M. Djafar Harun District Hospital in North Kolaka Regency.
\end{abstract}

Keywords: Environmental Accounting, Triple Bottom Line

\begin{abstract}
Abstrak
Penelitian ini bertujuan untuk mengetahui penerapan akuntansi lingkungan yang ditinjau dari konsep Triple Bottom Line pada RSUD H. M. Djafar Harun Kabupaten Kolaka Utara. Penelitian ini menggunakan penelitian deskriptif kualitatif. Pengumpulan data menggunakan data primer dan sekunder dengan wawancara mendalam dengan informan yang berada pada kawasan RSUD H. M. Djafar Harun Kabupaten Kolaka Utara. Hasil penelitian menunjukan bahwa akuntansi lingkungan yang dilaksanakan oleh RSUD H. M. Djafar Harun Kabupaten Kolaka Utara secara umum telah memenuhi konsep triple bottom line yang mencakup pada tiga unsur utama yaitu profit, people dan planet. Tanggung jawab ekonomi (profit) dapat dilihat pada produk-produk kesehatan yang dihasilkan dari kegiatan pelayanan kesehatan lainnya telah dilakukan perkembangan. Tanggung jawab lingkungan (planet) dapat dilihat dari program-program CSR bidang lingkungan secara nyata dilakukan untuk menyelamatkan dan melestarikan lingkungan seperti penanaman pohon dan tempat pembuangan limbah. Tanggung jawab sosial (people) secara nyata dilaksanakan melalui aktivitas CSR pada bantuan sarana kesehatan. Hal ini berarti bahwa prinsip pembangunan keberlanjutan yang menyebutkan bahwa manusia dan lingkungan bagian yang integral sebuah roda perputaran bisnis telah dilakukan RSUD H. M. Djafar Harun Kabupaten Kolaka Utara.
\end{abstract}

Kata Kunci: Akuntansi Lingkungan, Triple Bottom Line 
Invoice: Jurnal Ilmu Akuntansi

p-ISSN: 2714-6359 e-ISSN: 2714-6340

Vol.2 Nomor 2 September 2020

\section{PENDAHULUAN}

Perekonomian modern seperti saat ini telah memunculkan berbagai isu yang berkaitan dengan lingkungan seperti pemanasan global, ekoefisiensi, dan kegiatan industri lain yang memberi dampak langsung terhadap lingkungan sekitarnya (Agustia, 2010). Menurut Hilman (2007), keadaan lingkungan di dunia termasuk di Indonesia saat ini sudah memprihatinkan, dan salah satu masalah lingkungan hidup dimaksud adalah pemanasan global (global warming). Isu pemanasan global telah menjadi pembahasan yang hangat dibicarakan di berbagai negara. Salah satu sumber penyebab terjadinya pemanasan global yaitu akibat adanya eksploitasi alam yang dilakukan oleh manusia tanpa pertanggungjawaban.

Berkembangnya dunia industri tidak bisa dipungkiri menimbulkan efek permasalahan terhadap lingkungan, dimana pelaku industri seringkali mengabaikan dampak yang ditimbulkan bagi lingkungan, seperti timbulnya polusi air, tanah, udara dan adanya kesenjangan sosial pada lingkungan. Esensi sebuah industri adalah hubungan timbal balik dari lingkungan masyarakat kepada industri dalam hal ini tidak dapat dipisahkan (Rohelmy, dkk, 2015). Dari hal tersebut maka timbul kesadaran sehingga memunculkan berbagai upaya dari berbagai bidang untuk menanggulangi dan menemukan solusi atas permasalahan lingkungan ini, dan salah satunya adalah dari sisi akuntansi sehingga timbullah akuntansi lingkungan. Kerusakan lingkungan mulai banyak dirasakan oleh masayarakat di dunia seiring dengan perkembangan sektor industri.

\section{Bersamaan}

dengan

berkembangnya sektor industri maka banyak ditemukan dampak negatif yang ditimbulkan oleh aktivitas manusia. Di satu sisi, pertumbuhan industri tersebut memang berdampak positif, yaitu bertambahnya lapangan pekerjaan, sehingga pertumbuhan ekonomipun otomatis juga akan meningkat. Tapi di sisi lain, ada dampak negatif yang ditimbulkan dan mempengaruhi kelestarian lingkungan, yaitu ketika beberapa pabrik-pabrik tersebut tidak menghiraukan kelestarian lingkungan alam (Aniela, 2012). Saat ini, perusahaan dituntut tidak hanya mengutamakan pemilik dan manajemen, tetapi juga seluruh pihak yang terkait, seperti karyawan, konsumen, serta masyarakat dan lingkungan.

Perusahaan sebagai penyedia barang dan jasa bagi masyarakat mempunyai peran penting dalam perekonomian. Dalam menjalankan fungsinya, tentunya perusahaan juga melakukan interaksi dengan lingkungan. Menurut Utama (2008) perusahaan dalam melakukan bisnis pasti akan mempengaruhi keadaan lingkungan sekitar, baik secara positif maupun negatif. Proses bisnis yang dijalankan perusahaan melibatkan sumber daya yang ada di sekitarnya, terlebih bagi perusahaan sektor pertambangan yang memanfaatkan sumber daya alam sebagai bahan baku bisnis. Pemanfaatan sumber daya tersebut seringkali menimbulkan dampak negatif terhadap lingkungan, sosial, maupun ekonomi. Dampak negatif yang ditimbulkan tersebut mulai mendapat perhatian serius dari berbagai pihak, terlebih dampak atas keseimbangan lingkungan. 
Invoice: Jurnal Ilmu Akuntansi

p-ISSN: 2714-6359 e-ISSN: 2714-6340

Vol.2 Nomor 2 September 2020

Tuntutan terhadap perusahaan semakin besar dan perusahaan harus melihat sisi baru yaitu tanggung jawab perusahaan terhadap stakeholder, dan perusahaan tidak hanya mementingkan kepentingan manajemen, tetapi juga karyawan, konsumen serta masyarakat. Dengan demikian bila manusia sudah berdaya dan planet tetap lestari, profit atau keuntungan akan datang dengan sendirinya baik keuntungan yang dinikmati oleh manajemen sebagai agen pengelola entitas maupun investor sebagai pemilik entitas ekonomi tersebut. Jadi keuntungan atau profit bukanlah menjadi tujuan pertama dan utama, tetapi menjadi dampak dari kinerja perusahaan yang baik dan bertanggungjawab. Keuntungan yang akan bersifat jangka panjang dan berkesinambungan (Astuti (2012).

Perusahaan dalam operasinya seharusnya tidak mementingkan keuntungan semata, lebih dari itu tanggung jawab atas segala dampak yang ditimbulkan bagi sosial dan lingkungan juga harus diperhatikan. Dalam penerapan akuntansi lingkungan ada salah satu teori triple bottom line di mana teori ini tidak hanya melihat dari aspek profit (keuntungan) namun juga melihat dari aspek people (masyarakat) dan planet (lingkungan). Triple bottom line theory mengimplikasikan bahwa perusahaan harus lebih mengutamakan kepentingan stakeholder (semua pihak yang terlibat dan terkena dampak dari kegiatan yang dilakukan perusahaan) daripada kepentingan shareholder (pemegang saham) (Neviana, 2010).

Konsep triple bottom line mengimplikasikan bahwa perusahaan harus lebih mengutamakan kepentingan stakeholder (semua pihak yang terlibat dan terkena dampak dari kegiatan yang dilakukan perusahaan) daripada kepentingan shareholder (pemegang saham).

Kepentingan stakeholder ini dapat dirangkum menjadi tiga bagian yaitu kepentingan dari sisi keberlangsungan laba (Profit), sisi keberlangsungan masyarakat (People), dan sisi keberlangsungan lingkungan hidup (Planet). Profit di sini lebih dari sekadar keuntungan. Profit di sini berarti menciptakan fair trade dan ethical trade dalam berbisnis. People menekankan pentingnya praktik bisnis suatu perusahaan yang mendukung kepentingan tenaga kerja. Secara lebih spesifik, konsep ini melindungi kepentingan tenaga kerja dengan menentang adanya eksploitasi yang mempekerjakan anak di bawah umur, menerapkan pembayaran upah yang wajar, lingkungan kerja yang aman dan jam kerja yang dapat ditoleransi. Bukan hanya itu, konsep ini juga meminta perusahaan memperhatikan kesehatan dan pendidikan bagi tenaga kerja. Planet berarti mengelola dengan baik penggunaan energi, terutama atas sumber daya alam yang tidak dapat diperbarui. Mengurangi hasil limbah produksi dan mengolah kembali limbah agar menjadi aman bagi lingkungan, pemakaian energi, merupakan praktik yang banyak dilakukan oleh perusahaan yang telah menerapkan konsep ini (Felisia, Amelia Limijaya, 2014).

Hal ini karena keberadaan perusahaan tidak terlepas dari kepentingan dari berbagai pihak. Salah satunya adalah dukungan lingkungan. Sebuah perusahaan dikatakan memiliki kepedulian terhadap permasalahan lingkungan hidup jika perusahaan 
tersebut memiliki perhatian terhadap permasalahan lingkungan hidup di sekitarnya (Musyarofah, 2013). Salah satunya adalah dukungan lingkungan. Seringkali usaha peningkatan produktivitas dan efisiensi mengakibatkan penurunan kualitas lingkungan, berupa pencemaran udara, air, dan pengurangan fungsi tanah (Astuti, 2012).

Akuntansi lingkungan kerapkali dikelompokkan dalam wacana akuntansi sosial. Hal ini terjadi karena kedua diskursus (akuntansi lingkungan dan akuntansi sosial) tersebut memiliki tujuan yang sama, yaitu menginternalisasi eksternalitas (eksternalitas lingkungan sosial dan lingkungan ekologis), baik positif maupun negatif, ke dalam laporan keuangan perusahaan (Dewi, 2016). Menurut Cohen dan Robbins (2011) akuntansi lingkungan adalah kegiatan mengumpulkan, menganalisis dan mempersiapkan laporan terkait lingkungan dan data keuangan dengan maksud untuk mengurangi dampak dan biaya dari kerusakan lingkungan. Tujuannya adalah memberikan informasi mengenai kinerja operasional perusahaan yang berbasis pada perlindungan lingkungan. Perusahaan yang hanya mementingkan profit dan tidak peduli pada lingkungan akan terkena externalities berupa boikot dari konsumen, protes dari aktivis lingkungan hidup, protes dari pemegang sahamnya dan mungkin dari karyawannya sendiri (Martusa, 2009).

Akuntansi lingkungan juga dapat menjadi alat manajemen lingkungan dan komunikasi kepada masyarakat atas kegiatan operasional perusahaan. Akuntansi lingkungan adalah suatu istilah yang berupaya untuk mengelompokkan pembiayaan yang dilakukan perusahaan dan pemerintah dalam melakukan konvensional lingkungan ke dalam pos lingkungan dan praktik bisnis perusahaan (Suartana, 2015).

Akuntansi lingkungan merupakan sarana untuk melaporkan operasional suatu lembaga (negara/kota/perusahaan/organisasi) yang dikaitkan dengan lingkungan. Tujuannya adalah meningkatkan efisiensi pengelolaan lingkungan dengan melakukan penilaian kegiatan lingkungan dari sudut pandang biaya (environmental costs) dan manfaat atau efek (economic benefit), serta menghasilkan efek perlindungan lingkungan (environmental protection) (Ikhsan, 2008). Akuntansi lingkungan merupakan sarana untuk melaporkan operasional suatu lembaga (negara/kota/perusahaan/organisasi) yang dikaitkan dengan lingkungan.

Tujuannya adalah memberikan informasi mengenai kinerja operasional perusahaan yang berbasis pada perlindungan lingkungan. Perusahaan yang hanya mementingkan profit dan tidak peduli pada lingkungan akan terkena externalities berupa boikot dari konsumen, protes dari aktivis lingkungan hidup, protes dari pemegang sahamnya dan mungkin dari karyawannya sendiri. Walaupun pada kenyataannya ada beberapa perusahaan yang merekayasa laporan keuangan supaya terlihat ikut serta dalam perlindungan lingkungan (Martusa, 2009).

Penerapa akuntansi lingkungan tidak hanya di terapkan pada perusahaan profit namun juga pada perusahaan nonprofit, rumah sakit adalah salah satu 
Invoice: Jurnal Ilmu Akuntansi

p-ISSN: 2714-6359 e-ISSN: 2714-6340

Vol.2 Nomor 2 September 2020

perusahaan non-profit. Menurut Deegan (2003), konsep akuntansi lingkungan dapat diterapkan juga untuk organisasi pemerintah (public government) dan non-corporate stakeholders. Penerapan akuntansi lingkungan dalam aktivitas Rumah Sakit merupakan langkah awal yang menjadi solusi masalah lingkungan tersebut. Penerapan akuntansi lingkungan akan mendorong kemampuan untuk meminimalkan masalah lingkungan yang dihadapinya. Konsep ini masih terdengar baru di kalangan Rumah Sakit. Selama ini, konsep ini hanya diterapkan bagi entitasentitas bisnis yang bersifat profit oriented (swasta). Padahal Rumah Sakit juga merupakan unit yang tidak terlepas dari permasalahan sosial-lingkungan.

Dampak dari adanya masalah lingkungan semakin beragam. Tak sedikit dari masalah tersebut yang disebabkan oleh kegiatan operasi entitas usaha yang mengabaikan kelestarian lingkungan. Suatu perusahaan atau organisasi baik itu milik pemerintah ataupun swasta yang dalam pelaksanaan operasinya menimbulkan kerusakan ekosistem karena adanya limbah produksi perusahaan. Seperti halnya Rumah Sakit sebagai perusahaan jasa yang bergerak di bidang kesehatan memberi dampak positif dan juga memberi dampak negatif bagi masyarakat yaitu limbah yang dihasilkan dari kegiatan operasionalnya yang berpotensi mencemari lingkungan dan menularkan penyakit. Limbah rumah sakit adalah semua limbah yang dihasilkan oleh kegiatan rumah sakit dan kegiatan penunjang lainnya.

Terdapat beberapa penelitian sebelumnya yang bekaitan dengan akuntansi lingkungan berdasarkan triple bottom line. Penelitian yang dilakukan oleh Ismie Dzakky Fatimah (2011) yang berjudul Penerapan Akuntansi Lingkungan (Studi Kasus Pada PT Semen Indonesia (Persero) Tbk Tuban). Pada penelitian tersebut membahas mengenai pengungkapan akuntansi lingkungan melalui konsep triple bottom line dalam program CSR-nya.

Hasil penelitiannya menunjukkan bahwa secara keseluruhan PT Semen Indonesia telah menerapkan perspektif triple bottom line dalam program CSRnya. Perusahaan telah melakukan program sosial untuk masyarakat di sekitar perusahaan, pendidikan, infrastruktur, serta program pengembangan masyarakat berbasis kelestarian lingkungan dan meningkatkan standar hidup di sekitar perusahaan. Kurangnya dukungan dan koordinasi dengan pemerintah Tuban dan masyarakat menjadi kendala dalam implementasi program CSR. Selain itu, program CSR cenderung diarahkan sebagai program amal yang karenanya program tidak memiliki hubungan timbal balik sepenuhnya dengan masyarakat.

Selanjutnya penelitian yang dilakukan oleh Muqodim (2013) berjudul Triple Bottom Line Reporting Dalam Pelaporan Tahunan Perusahaan Go Public Di Indonesia. Pada penelitian ini membahas tentang permasalahan sosial dan lingkungan melalui pelaporan keuangan tahunan yang diterbitkan. Tujuan utamanya adalah mengenalkan kepada publik adanya konsep Triple Bottom Line Reporting. Sehingga hasil dari penelitian ini adalah pada tahun 2010, terdapat $72 \%$ perusahaan melaporkan kinerja sosial dan lingkungan, sementara pada tahun 2011, terdapat $77 \%$ perusahaan melaporkan 
Invoice: Jurnal Ilmu Akuntansi

p-ISSN: 2714-6359 e-ISSN: 2714-6340

Vol.2 Nomor 2 September 2020

informasi tersebut. Namun, dari perspektif standar pelaporan GRI, data menunjukkan bahwa informasi kinerja lingkungan dan sosial belum dilaporkan sepenuhnya.

Terkait dengan penerapan akuntansi lingkungan, peneliti mengambil objek di RSUD H. M. Djafar Harun Kabupaten Kolaka Utara yang merupakan sebuah perusahaan yang bergerak dalam bidang pelayanan jasa kesehatan masyarakat. Fenomena yang terjadi pada RSUD H. M. Djafar Harun Kabupaten Kolaka Utara dilihat dari rekomendasi yang dikeluarkan Kementerian Kesehatan (Kemenkes) RI bertanggal 15 Juli 2019 yang berisi bahwa penurunan kelas dari Kelas $C$ ke kelas D pada RS Umum Daerah H. M. Djafar Harun. Menurut Direktur Jenderal Pelayanan Kesehatan Kemenkes, Bambang Wibowo, review dilakukan untuk merekam kompetensi rumah sakit, baik dari aspek sumber daya manusia (SDM) maupun alat-alat kesehatan (inilahsultra.com, 2019). Penurunan kelas ini didasari dari Isu pengelolaan lingkungan Rumah Sakit yaitu salah satu upaya untuk menciptakan lingkungan Rumah Sakit yang bersih, nyaman dan higienis.

Berkembangnya perusahaan atau organisasi baik itu milik pemerintah ataupun swasta yang dalam pelaksanaan operasinya menimbulkan kerusakan ekosistem karena adanya limbah produksi perusahaan yang tentu memerlukan alokasi biaya penanganan khusus (Aminah dan Noviyani, 2014). Mengingat dampak yang mungkin timbul, maka diperlukan upaya pengelolaan yang baik. Dari penjelasan tersebut, apabila sistem pengelolaan limbah tidak dilakukan dengan baik, potensi Rumah Sakit untuk mencemari lingkungan cukup besar.Biaya yang harus dikeluarkan untuk mengatasi dampaknya juga besar. Rumah Sakit tidak akan terlepas dari keinginan melakukan kontrol terhadap apa yang dilakukan Rumah Sakit secara sistematis sehingga tidak menimbulkan dampak negatif misalnya polusi udara, limbah produksi, kesenjangan sosial dan lain sebagainya dan dampak semacam inilah yang dinamakan Externality. Sampai saat ini usaha pemerintah dalam memenuhi kebutuhan masyarakat akan kesehatan masih belum dapat memenuhi harapan masyarakat.

Banyak anggota masyarakat yang mengeluh dan merasa tidak puas dengan pelayanan yang diberikan oleh Rumah Sakit baik itu dari segi pemeriksaan yang kurang diperhatikan oleh petugas kesehatan, lama waktu pelayanan, keterampilan petugas, sarana atau asilitas, kebersihan, serta waktu tunggu untuk mendapatkan pelayanan. Kondisi pelayanan yang ideal realistisnya serta sesuai dengan harapan masyarakat sangat susah untuk diwujudkan dalam pemerintahan.

Berangkat dari gambaran tersebut, maka peneliti akan melakukan penelitian tentang penerapan akuntansi lingkungan pada organisasi sektor publik khususnya Rumah Sakit Umum Daerah (RSUD) H. M. Djafar Harun Kabupaten Kolaka Utara untuk mengetahui bagaiamana penerapan akuntansi lingkungan berdasarkan triple bottom line yang dalam konsep tersebut tidak hanya berfokus pada profit (keuntungan) tetapi juga berfokus pada people (masyarakat) dan planet (lingkungan). 
Invoice: Jurnal Ilmu Akuntansi

p-ISSN: 2714-6359 e-ISSN: 2714-6340

Vol.2 Nomor 2 September 2020

\section{TINJAUAN PUSTAKA}

\subsection{Teori Legitimasi (Legitimacy} Theory)

Dowling dan Preffer (1975), teori legitimasi menjelaskan perilaku organisasi mengenai batasan-batasan dalam berperilaku terhadap lingkungan. Teori legitimasi berfokus pada interaksi antara perusahaan dengan masyarakat di mana perusahaan dapat berhasil atau menghadapi kegagalan tergantung pada perilakunya terhadap lingkungan. Menurut Villiers dan Staden (2006), legitimasi merupakan hal-hal yang penting bagi organisasi karena mengandung batasan-batasan, normanorma, nilai-nilai sosial dan reaksi terhadap batasan tersebut, mendorong pentingnya analisis perilaku organisasi dengan memperhatikan lingkungan. Proses legitimasi dapat membuat sesuatu dapat menjadi sah dalam hukum, terlihat baik dan diterima dengan normatif didalam lingkungan masyarakat. Legitimasi juga memprediksi bahwa perusahaan akan melakukan tindakan apapun yang dipandangnya perlu dalam rangka mempertahankan reputasinya (image) sebagai perusahaan legitimate.

Legitimacy Theory menjelaskan bagaimana kepekaan perusahaan agar dapat bertanggungjawab terhadap lingkungannya. Berdirinya perusahaan tidak terlepas dari dukungan masyarakat, oleh karena itu harus memperhatikan kepentingan masyarakat. Untuk menjalankan operasional perusahaan, maka mengacu pada kontrak sosial (social contract) mencakup hak dan kewajiban dan menyesuaikan dengan kondisi masyarakat. Kontrak sosial menjadi media dalam pencapaian tujuan perusahaan yang diiringi dengan tanggung jawab terhadap masyarakat (Wardani dan Januarti, 2013).

Ahmad dan Sulaiman (2004) teori legitimasi didasarkan pada pengertian kontrak sosial yang diimplikasikan antara institusi sosial dan masyarakat. Teori legitimasi juga menjelaskan bahwa praktik pengungkapan tanggung jawab perusahaan harus dilaksanakan sedemikian rupa agar aktivitas dan kinerja perusahaan dapat diterima oleh masyarakat. Ghozali dan Chariri (2007) menjelaskan bahwa guna melegitimasi aktivitas perusahaan di mata masyarakat, perusahaan cenderung menggunakan kinerja berbasis lingkungan dan pengungkapan informasi lingkungan.

Teori legitimasi merupakan teori yang paling sering digunakan terutama ketika berkaitan dengan wilayah sosial dan akuntansi lingkungan. Meskipun masih terdapat pesimisme yang kuat yang dikemukakan oleh banyak peneliti, teori ini telah dapat menawarkan sudut pandang yang nyata mengenai pengakuan sebuah perusahaan secara sukarela oleh masyarakat. Legitimasi dapat memberikan mekanisme yang kuat untuk memahami pengungkapan sukarela untuk lingkungan dan sosial yang dilakukan oleh perusahaan, dan pemahaman ini yang nantinya akan mengarah ke debat publik yang kritis, lebih jauh lagi teori legitimasi menunjukan kepada peneliti dan masyarakat luas jalan untuk lebih peka terhadap isi pengungkapan perusahaan. Teori legitimasi menganjurkan perusahaan untuk meyakinkan bahwa aktivitas dan kinerjanya dapat diterima oleh masyarakat. 
Invoice: Jurnal Ilmu Akuntansi

p-ISSN: 2714-6359 e-ISSN: 2714-6340

Vol.2 Nomor 2 September 2020

Legitimasi dalam sebuah perusahaan akan diperoleh, jika terdapat kesamaan antara hasil dengan yang diharapkan oleh masyarakat dari perusahaan, sehingga tidak ada tuntutan dari masyarakat, perusahaan dapat melakukan pengorbanan social sebagai refleksi dari perhatian perusahaan terhadap masyarakat (Deegan, 2002). Teori legitimasi memfokuskan pada interaksi antara perusahaan dengan masyarakat dan yang melandasi teori ini adalah "kontrak sosial" yang terjadi antara perusahaan dengan masyarakat dimana perusahaan beroperasi dan menggunakan sumber ekonomi. Dengan hal tersebut teori ini menjadi landasan bagi perusahaan untuk memperhatikan apa yang menjadi harapan masyarakat dan mampu menyelaraskan nilai-nilai perusahaannya dengan norma-norma sosial yang berlaku ditempat perusahaan tersebut melangsungkan kegiatan usaha atau bisnisnya.

Legitimasi pada perusahaan yang peduli lingkungan itu penting agar perusahaan tersebut dapat diterima oleh lingkungan tempat dimana perusahaan tersebut berada dan dapat terus berkelanjutan kemudian hari (Agustina dan Tarigan, 2016). Dari hal tersebut menjelaskan bahwa guna melegitimasi aktivitas perusahaan dimata masyarakat, perusahaan cenderung menggunakan kinerja berbasis lingkungan dan pengungkapan informasi lingkungan yang baik. Perusahaan menggunakan laporan tahunan mereka untuk menggambarkan kesan tanggung jawab lingkungan, sehingga mereka diterima oleh masyarakat (Soelistyoningrum, 2011: 32). Dengan adanya penerimaan dari masyarakat tersebut diharapkan dapat meningkatkan nilai perusahaan sehingga dapat meningkatkan laba perusahaan. Legitimasi dapat diperoleh melalui strategi komunikasi dengan mengirimkan informasi yang akurat dan dapat dipercaya (Shockley-Zalabak, et.Al, 2003). Narrative text pada annual report merupakan media yang tepat digunakan perusahaan dalam hal memperoleh legitimasi (Budiani, 2011: 27). Hal ini diperkuat oleh Aerts (1994) dalam Budiani (2011: 27) yang mengatakan bahwa narrative text merupakan salah satu alat yang dapat digunakan manajemen perusahaan untuk membuat aktivitas dan hasil dari perusahaan tersebut terlihat legitimate.

Teori legitimasi penting bagi organisasi karena teori legitimasi didasari oleh batasan-batasan, normanorma, nilai-nilai dan peraturan sosial yang membatasi perusahaan agar memperhatikan kepentingan sosial dan dampak dari reaksi social yang dapat ditimbulkan. Dengan melakukan pengungkapan sosial (kinerja lingkungan), perusahaan merasa keberadaan dan aktivitasnya terlegitimasi. Organisasi yang dianggap sah atau legitimate, lebih dipandang sebagai organisasi yang dipercaya, layak, bermakna dan memiliki prediksi. Selain itu, organisasi dianggap lebih legitimate bilamana organisasi tersebut mudah untuk dimengerti, bukan hanya sekedar diinginkan (Budiani, 2011: 26).

Teori legitimasi menyiratkan bahwa perusahaan diberi pertumbuhan kesadaran tentang masyarakat dan kepedulian, perusahaan akan mengambil tindakan untuk menjamin kegiatan dan kinerja mereka diterima oleh masyarakat. Teori legitimasi juga terkait dengan pengungkapan sosial menyiratkan bahwa alasan mengapa 
Invoice: Jurnal Ilmu Akuntansi

p-ISSN: 2714-6359 e-ISSN: 2714-6340

Vol.2 Nomor 2 September 2020

perusahaan mengungkapkan aktivitas lingkungan mereka ialah hal yang diperlukan oleh masyarakat dimana perusahaan beroperasi, dan kegagalan untuk mengungkapkan bisa memiliki implikasi yang merugikan bagi perusahaan. Maka perusahaan yang mempunyai kepedulian terhadap lingkungan disekitarnya maka masyarakat juga akan yakin bahwa perusahaan ini tidak akan merugikan lingkungan tempat hidup mereka, maka dari itulah perusahaan harus melegitimasi masyarakat dan sekitar lingkungannya.

\subsection{Stakeholder Theory}

Stakeholder theory merupakan teori yang dikembangkan oleh R. Edward Freeman (1984). Teori stakeholder artinya sebagai kumpulan kebijakan dan praktik yang berhubungan dengan stakeholder, nilai-nilai, pemenuhan ketentuan hukum, penghargaan masyarakat dan lingkungan, serta komitmen dunia usaha untuk kontribusi dalam pembangunan secara berkelanjutan. Stakeholder theory dimulai dengan asumsi bahwa nilai (value) secara eksplisit dan tak dipungkiri merupakan bagian dari kegiatan usaha (Freeman, 2002).

Pengungkapan informasi keuangan, sosial, dan lingkungan merupakan dialog antara perusahaan dengan stakeholder-nya dan menyediakan informasi mengenai aktivitas perusahaan yang dapat mengubah persepsi dan ekspektasi (Adam dan McNicholas, 2007). Perusahaan akan berusaha untuk mencapai harapan stakeholder yang berkuasa dengan penyampaian pengungkapan, termasuk pelaporan aktivitas sosial dan lingkungan.
Pengungkapan tersebut dilakukan dengan harapan dapat memenuhi kebutuhan stakeholder-nya serta mendapatkan dukungan dari stakeholder-nya demi keberlangsungan perusahaan.

Perusahaan adalah bagian dari beberapa elemen yang membentuk masyarakat dalam sistem sosial. Kondisi tersebut menciptakan sebuah hubungan timbal balik antara perusahaan dan para stakeholder. Hal ini berarti perusahaan harus melaksanakan peranannya secara dua arah yaitu untuk memenuhi kebutuhan perusahaan itu sendiri maupun stakeholders. Menurut Freeman (2001) teori stakeholder adalah teori yang menggambarkan kepada pihakmana saja (stakeholder) perusahaan bertanggung jawab. Januarti dan Apriyanti (2005) mengemukakan bahwa teori stakeholder mengasumsikan bahwa eksistensi perusahaan memerlukan dukungan stakeholder sehingga aktivitas perusahaan juga mempertimbangkan persetujuan dari stakeholder.

Stakeholders merupakan individu, sekelompok manusia, komunitas atau masyarakat baik secara keseluruhan maupun secara parsial yang memiliki hubungan serta kepentingan terhadap perusahaan. Ghozali dan Chariri (2007) menjelaskan bahwa stakeholders theory mengatakan bahwa perusahaan bukanlah entitas yang hanya beroperasi untuk kepentingannya sendiri namun harus memberikan manfaat bagi stakeholder-nya (pemegang saham, kreditor, konsumen, supplier, pemerintah, masyarakat, analis, dan pihak lain).

Teori stakeholder digunakan sebagai dasar untuk menganalisis 
Invoice: Jurnal Ilmu Akuntansi

p-ISSN: 2714-6359 e-ISSN: 2714-6340

Vol.2 Nomor 2 September 2020

kelompok-kelompok yang mana perusahaan harus bertanggung jawab (Moir, 2001). Definisi stakeholder menurut Freeman (1984) dalam Moir (2001) adalah setiap kelompok atau individu yang dapat mempengaruhi atau dipengaruhi oleh pencapaian tujuan organisasi. Stakeholder khususnya dapat dibedakan kedalam stakeholder primer dan sekunder. Clarkson (1995) dalam Moir (2001) mendefinisikan stakeholder primer sebagai seseorang atau kelompok yang tanpanya perusahaan tidak dapat going concern, meliputi: shareholder dan investor, karyawan, konsumen dan pemasok, bersama dengan yang didefinisikan dengan shareholder public, yaitu: pemerintah dan komunitas yang menyediakan infrastruktur dan pasar, yang undang-undang dan peraturannya harus ditaati, dan kepadanya pajak dan kewajibannya harus dibayar. Kelompok stakeholder sekunder didefinisikan sebagai mereka yang mempengaruhi, atau dipengaruhi perusahaan, namun mereka tidak berhubungan dengan transaksi dengan perusahaan dan tidak esensial kelangsungannya.

Stakeholder pada dasarnya dapat mengendalikan atau memiliki kemampuan untuk mempengaruhi pemakaian sumber-sumber ekonomi yang digunakan perusahaan. Oleh karena itu power stakeholder ditentukan oleh besar kecilnya power yang dimiliki stakeholder atas sumber tersebut (Ghozali dan Chariri, 2007). Power tersebut dapat berupa kemampuan untuk membatasi pemakaian sumber ekonomi yang terbatas (modal dan tenaga kerja), akses terhadap media yang berpengaruh, kemampuan untuk mengatur perusahaan, atau kemampuan untuk mempengaruhi konsumsi atas barang dan jasa yang dihasilkan perusahaan (Deegan, 2000 dalam Ghozali dan Chariri, 2007). Oleh karena itu, ketika stakeholder mengendalikan sumber ekonomi yang penting bagi perusahaan, maka perusahaan akan bereaksi dengan cara-cara yang memuaskan keinginan stakeholder. Atas dasar argumen diatas, teori stakeholder umumnya berkaitan dengan caracara yang digunakan perusahaan untuk memanage stakeholder-nya. Cara-cara yang dilakukan untuk me-manage stakeholdernya tergantung pada strategi yang diadopsi perusahaan (Ullman, 1985).

Ullman (1985) mengatakan bahwa strategi aktif adalah apabila perusahaan berusaha mempeangaruhi hubungan organisasinya dengan stakeholder yang dipandang berpengaruh, sedangkan perusahaan yang mengadopsi strategi pasif cenderung tidak terus menerus memonitor aktivitas stakeholder dan secara sengaja tidak mencari strategi optimal untuk menarik perhatian stakeholder (Angling Mahatma Pian, 2010).

\subsection{Akuntansi Lingkungan}

Akuntansi lingkungan merupakan ilmu akuntansi yang bekerja dalam ruang lingkup environmental management system. Pendapat lain juga mengatakan bahwa akuntansi sosial lingkungan mengidentifikasi, menilai, dan mengukur aspek penting dari kegiatan sosial ekonomi perusahaan dan negara dalam memelihara kualitas hidup masyarakat sesuai dengan tujuan yang telah ditetapkan (Haniffa, 2002 dalam Anonim; 2011). Sedangkan akuntansi sosial lingkungan yang didefinisikan oleh Ramanathan (1996 dalam Anonim; 2011) adalah proses seleksi variabelvariabel kinerja sosial tingkat 
Invoice: Jurnal Ilmu Akuntansi

p-ISSN: 2714-6359 e-ISSN: 2714-6340

Vol.2 Nomor 2 September 2020

perusahaan, ukuran dan prosedur pengukuran, yang secara sistematis mengembangkan formasi yang bermanfaat untuk mengevaluasi kinerja sosial perusahaan dan mengkomunikasikan informasi kepada kelompok sosial yang tertarik baik di dalam maupun di luar perusahaan.

"Gray, Bebbington and Walters define environmental accounting as a management tool addressing all areas of accounting that may be affected by the response of business organizations to environmental issues, including the new area of eco-accounting. Another definition was suggested by the Public Accounts and Estimates Committee, which defined it as a process, which provides information on the environment and the impact of human activity on the environment that is useful in making appropriate decisions at various levels of management."

Gray, Bebbington and Walters mendefiniskan akuntansi lingkungan sebagai alat untuk menangani semua bidang akuntansi manajemen yang dapat dipengaruhi oleh organisasi bisnis untuk isu lingkungan, termasuk daerah barueco-akuntansi. Definisi lain oleh Komite Akuntan Publik dan Estimasi, yang mendefinisikan sebagai sebuah proses yang memberikan informasi tentang lingkungan dan dampak aktivitas manusia pada lingkungan dalam mengambil keputusan yang tepat pada tingkat manajemen (Małgorzata Kamieniecka, 2013:56).

Berdasarkan hakikat dari sistem manajemen lingkungan, maka dengan meminjam definisi dari Ggray dan Bebington (2001) dalam Lako (2011:124), area akuntansi lingkungan mencakup: (1) risiko-risiko atau kewajiban kontinjen perusahaan, (2) revaluasi aset dan proyeksi-proyeksi kapital, (3) analisis biaya dalam areaarea penting seperti energi, limbah dan proteksi lingkungan, (4) penafsiran investasi yang mempertimbangkan faktor-faktor lingkungan, (5) pengembangan sistem informasi dan sistem akuntansi baru yang mencakup semua kinerja lingkungan, (6) penilaian terhadap costs dan benefits dari programprogram perbaikan lingkungan, (7) pengembangan teknik-teknik akuntansi untuk mengungkap aset, kewajiban dan cost dan terminologogi-terminologi ekologi dan non financial.

Pentingnya penggunaan akuntansi lingkungan bagi perusahaan ini tercantum dalam fungsi dan peran akuntansi lingkungan yang terbagi atas dua bagian yaitu (1) fungsi internal, merupakan fungsi yang berkaitan dengan pihak internal perusahaan itu sendiri. Pihak internal adalah pihak yang menyelengggarakan usaha, seperti rumah tangga konsumen dan rumah tangga produksi maupun jasa lainnya (Ikhsan, 2008:18). Adapun yang menjadi aktor dan faktor dominan pada fungsi internal ini adalah pimpinan perusahaan. Sebab pimpinan perusahaan merupakan orang yang bertanggungjawab dalam setiap pengambilan keputusan maupun penentuan setiap kebijakan internal perusahaan. Fungsi internal memungkinkan untuk mengatur biaya konservasi lingkungan dan menganalisis biaya dari kegiatan-kegiatan konservasi lingkungan yang efektif dan efisien serta sesuai dengan pengambilan keputusan. (2) fungsi eksternal merupakan fungsi yang berkaitan dengan aspek pelaporan keuangan. Pada fungsi ini faktor paling penting yang perlu diperhatikan perusahaan adalah pengungkapan hasil 
dari kegiatan konservasi lingkungan dalam bentuk data akuntansi.

$$
\text { Undang-Undang }
$$

Republik

Indonesia No. 23 tahun 1997 mengenai pengelolaan lingkungan hidup, lingkungan hidup adalah kesatuan ruangan dengan semua benda, daya, keadaan, dan makhluk hidup termasuk manusia dan perilakunya, yang mempengaruhi kelangsungan perikehidupan dan kesejahteraan manusia serta makhluk hidup lain. Lingkungan hidup juga bisa didefinisikan sebagai (Wikipedia: 2008):

a. Daerah dimana sesuatu mahluk hidup berada.

b. Keadaan atau kondisi yang melingkupi suatu makhluk hidup.

c. Keseluruhan keadaan yang meliputi sekumpulan mahluk hidup, terutama kombinasi dari berbagai kondisi fisik luar mahluk hidup yang mempengaruhi pertumbuhan, perkembangan dan kemampuan mahluk hidup untuk bertahan serta merupakan gabungan dari kondisi sosial dan budaya yang berpengaruh pada keadaan suatu individu mahluk hidup atau suatu komunitas makhluk hidup.

\section{Akuntansi lingkungan} dipertimbangkan karena akan menjadi perhatian bagi pemegang saham dengan cara mengurangi biaya yang berhubungan dengan lingkungan sehingga diharapkan dengan pengurangan biaya lingkungan tersebut akan menciptakan kualitas lingkungan yang lebih baik. Selain itu, tujuan akuntansi lingkungan juga untuk menjembatani kepentingan perusahaan dengan pemangku kepentingan secara menyeluruh. Hal tersebut untuk mengetahui kegiatan perusahaan dalam menangani pencemaran lingkungan serta kewajiban perusahaan atas masalah tersebut melalui laporan keuangan perusahaan. Selain itu, hal tersebut juga bertujuan untuk memenuhi tuntutan terhadap undang- undang yang menyangkut kewajiban lingkungan (environmental liabilities) (Hasyim, 2011).

\subsection{Triple Bottom Line Theory}

Istilah Triple Bottom Line dipelopori oleh Elkington dalam buku Cannibals With Forks. Dalam definisinya tentang Triple Bottom Line, Elkington menggunakan istilah profit, people, dan planet sebagai tiga garis (Elkington, 1998). Triple Bottom Line Accounting menekankan bahwa kinerja perusahaan tidak hanya diukur dengan indikator keuangan, melainkan juga menggunakan indikator non keuangan. Konsep Triple Bottom Line Accounting menyediakan kerangka kerja untuk mengukur kinerja bisnis dan keberhasilan organisasi menggunakan tiga jalur, yakni bidang ekonomi, sosial, dan lingkungan (Goel, 2010). Menurut (Foran, Lenzen, Dey, \& Bilek, 2005) konsep triple bottom line accounting secara luas dikembangkan sebagai cara dimana perusahaan dapat mewujudkan tujuan sosial yang lebih luas disamping meningkatkan nilai pemegang saham.

Triple Bottom Line Accounting (TBLA) telah menjadi isu utama dan hangat dibicarakan dalam berbagai kesempatan dan diwujudkan dalam tiga pilar yaitu people, profit dan planet. Teori triple bottom line dimana teori ini memberi pandangan bahwa jika sebuah perusahaan ingin mempertahankan kelangsungan hidupnya, maka perusahaan tersebut harus memperhatikan "3P". Selain mengejar 
Invoice: Jurnal Ilmu Akuntansi

p-ISSN: 2714-6359 e-ISSN: 2714-6340

Vol.2 Nomor 2 September 2020

keuntungan (profit), perusahaan juga harus memperhatikan dan terlibat pada pemenuhan kesejahteraan masyarakat (people) dan turut berkontribusi aktif dalam menjaga kelestarian lingkungan (planet) (Yusuf wibisono, 2007).

a. Profit (Keuntungan)

Profit atau keuntungan merupakan tujuan utama dan terpenting dalam setiap kegiatan usaha. Tidak dapat dipungkiri jika fokus utama dari seluruh kegiatan dalam perusahaan adalah mengejar profit dan mendongkrak harga saham setinggi-tingginya karena inilah bentuk tanggung jawab ekonomi yang paling esensial terhadap pemegang saham. Aktivitas yang dapat ditempuh untuk mendongkrak profit antara lain dengan meningkatkan produktivitas dan melakukan efiisensi biaya. Peningkatan produktivitas bisa diperoleh dengan memperbaiki manajemen kerja mulai penyederhanaan proses, mengurangi aktivitas yang tidak efisien, menghemat waktu proses dan pelayanan. Sedangkan efisiensi biaya dapat tercapai jika perusahaan menggunakan material sehemat mungkin dan memangkas biaya serendah mungkin.

b. People (Masyarakat)

People atau masyarakat merupakan stakeholders yang sangat penting bagi perusahaan, karena dukungan masyarakat sangat diperlukan bagi keberadaan, kelangsungan hidup, dan perkembangan perusahaan. Maka dari itu perusahaan perlu berkomitmen untuk berupaya memberikan manfaat sebesar-besarnya kepada masyarakat. Perlu disadari juga bahwa operasi perusahaan berpotensi memberi dampak kepada masyarakat. Karena itu perusahaan perlu untuk melakukan berbagai kegiatan yang dapat menyentuh kebutuhan masyarakat (Wibisono, 2007).

c. Planet (Lingkungan)

Planet atau Lingkungan adalah korban dari tindakan eksploitasi alam yang dilakukan manusia. Lingkungan juga merupakan sesuatu yang terkait dengan seluruh bidang dalam kehidupan manusia. Karena semua kegiatan yang dilakukan oleh manusia sebagai makhluk hidup selalu berkaitan dengan lingkungan misalnya air yang diminum, udara yang dihirup dan seluruh peralatan yang digunakan, semuanya berasal dari lingkungan. Begitu besar manfaat yang diterima oleh manusia membuat mereka lupa bahwa lingkungan pun harus di lestarikan kembali agar generasi selanjutnya masih bisa menikmati manfaat dari lingkungan yang bersih.

John Elkington (1997) konsep triple bottom line merupakan perluasan dari konsep akuntansi tradisional yang hanya membuat single bottom line tunggal yakni hasil-hasil keuangan dari aktivitas ekonomi perusahaan. Secara lebih rinci, Elkington menjelaskan triple bottom line sebagai berikut.

"The three lines of the triple bottom line represent society, the economy and the environment. Societ depend on the global ecosystem, whose hearh represents ultimate bottom line. The three line are not stable; they are in constant flux, due to social, political, economic and environmental pressures, cycle and conflicts."

Berdasarkan pengertian dan pemaparan di atas dapat disimpulkan bahwa aktivitas perusahaan yang berkaitan dengan ekonomi, sosial dan lingkungan sangat berkaitan dengan masyarakat. Konsep TBL 
Invoice: Jurnal Ilmu Akuntansi

p-ISSN: 2714-6359 e-ISSN: 2714-6340

Vol.2 Nomor 2 September 2020

mengimplikasikan bahwa perusahaan harus lebih mengutamakan kepentingan stakeholder (semua pihak yang terlibat dan terkena dampak dari kegiatan yang dilakukan perusahaan) daripada kepentingan shareholder (pemegang saham). Karena keuntungan merupakan inti dari dunia bisnis dan itu merupakan hal yang wajar. Maka, manusia sebagai pelaku industri hanya mementingkan bagaimana menghasilkan uang sebanyak-banyaknya tanpa melakukan upaya apapun untuk melestarikan lingkungan. Padahal dengan melestarikan lingkungan, manusia justru akan memperoleh keuntungan yang lebih, terutama dari sisi kesehatan, kenyamanan, di samping ketersediaan sumber daya yang lebih terjamin kelangsungannya (Deviarti Holly. 2012.).

Global Reporting Initiative (GRI), yang merupakan panduan pelaporan perusahaan untuk mendukung pembangunan berkelanjutan yang digagas oleh PBB lewat Coalition for Environmental Economies (CERES) dan (UNEP) pada tahun 1997. GRI merupakan organisasi non-profit yang mempromosikan keberlanjutan sosial, ekonomi, dan lingkungan. GRI menyediakan kerangka pelaporan keberlanjutan yang komprehensif bagi semua perusahaan dan organisasi yang banyak digunakan diseluruh dunia. Semakin banyak indikator yang diungkapkan dalam sustainability report maka semakin bagus kualitas dari sustainability report tersebut. Dalam penelitian ini indikator yang digunakan adalah GRI-G4 Guidelines menyebutkan bahwa, perusahaan harus menjelaskan dampak aktivitas perusahaan terhadap ekonomi, lingkungan dan sosial pada bagian standar disclosure. Sustainability report menggunakan standar dari GRI berisi 3 komponen yaitu:

1. Indikator Kinerja Ekonomi

2. Indikator Kinerja Lingkungan

3. Indikator Kinerja Sosial, terdiri dari empat sub-kategori, yaitu:

a) Indikator Ketenagakerjaan \& Kenyamanan Bekerja

b) Indikator Kinerja Hak Asasi Manusia

c) Indikator Kinerja Masyarakat

d) Indikator Kinerja Tanggung Jawab Produk

Adapun item-item yang digunakan dalam pengungkapan sustainability report adalah sebagai berikut:

berkaitan dengan perbaikan lingkungan. Pada pertengahan tahun 1990-an ketika istilah environmental accounting belum banyak dikenal hanya beberapa perusahaan saja yang menerapkannya, mula-mula dengan mengungkapkan masalah lingkungan. Hal ini dikarenakan berkaitan dengan keterbukaan perusahaan untuk mengungkapkan informasi lingkungan sebagai dampak dari aktivitas industri atau bisnis mereka. Kerusakan lingkungan adalah dampak intern bila perusahaan sangat bernafsu untuk mengejar laba dan pemupukan modal (Suartana, 2010).

Penerapan akuntansi lingkungan itu terkait dengan kepedulian mereka terhadap lingkungan itu sendiri, dan hal tersebut bahwa triple bottom line adalah suatu pengurustamaan pengelola dan kepedulian perusahaan dewasa ini. Triple bottom line telah menjadi isu utama dan diwacanakan dalam berbagai kesempatan dan diwujudkan dalam tiga pilar ialah laba, alam dan manusia. Bahwa dalam triple bottom line bukan hanya sekedar mencari laba namun juga 
Invoice: Jurnal Ilmu Akuntansi

p-ISSN: 2714-6359 e-ISSN: 2714-6340

Vol.2 Nomor 2 September 2020

memiliki perhatian terhadap manusia dan alam yang ada disekitarnya. Serta juga membuktikan bahwa teori legitimasi didasari oleh kontrak sosial yang terjadi antara perusahaan dengan masyarakat dimana perusahaan beroperasi dan menggunakan sumber daya ekonomi (Ghozali dan Chariri, 2007 dalam Nugroho dan Purwanto, 2013). Legitimasi organisasi dapat dilihat sesuatu yang diberikan masyarakat kepada perusahaan dan sesuatu yang diinginkan atau dicari dari masyarakat. Hal ini ditunjukkan dengan pengungkapan triple bottom line yang dilakukan oleh perusahaan sebagai wujud legitimasi terhadap masyarakat. Dan hal tersebut menguraikan dampak organisasi perusahaan terhadap ekonomi, sosial dan lingkungan. Salah satu model awal yang digunakan oleh perusahaan dalam menyusun sustainability report mereka adalah dengan mengadopsi metode akuntansi yang dinamakan triple bottom line (Nugroho dan Purwanto, 2013). Secara detail tiga pilar TBL yang diungkapkan oleh Omimi dan Kingsley (2013) serta Onyali dan Innocent (2014) adalah:

a. Planet (Lingkungan), Dalam pilar ini perusahaan harus turut serta dalam menjaga kelestarian lingkungan hidup dan keberlanjutan keberagaman hayati. Dengan berfokus pada lingkungan dan keberlanjutan, perusahaan memastikan bahwa bahan yang mereka gunakan diproses menggunakan metode dan teknik yang baik. Hal tersebut mengacu pada praktik-praktik lingkungan yang berkelanjutan. Bahwa sebuah perusahaan ada untuk memberikan manfaat terhadap tatanan alam sebanyak mungkin atau setidaknya tidak merugikan dan meminimalkan dampak terhadap lingkungan, antara lain, hati-hati mengelola konsumsi energi dan non-energi terbarukan dan mengurangi limbah manufaktur serta render limbah kurang beracun sebelum membuangnya, dan dengan cara yang aman dan legal. Seiring berjalannya waktu kelestarian lingkungan tentu saja lebih menguntungkan untuk bisnis dalam jangka panjang. Selain masyarakat sekitar, jika perusahaan ingin tetap eksis maka harus disertakan pula laporan tanggung jawab terhadap lingkungan. Lingkungan adalah sesuatu yang terkait dengan seluruh bidang kehidupan manusia. Namun sayangnya, sebagian besar dari kita masih kurang peduli dengan lingkungan sekitar. Hal ini disebabkan karena tidak ada keuntungan langsung yang timbul didalamnya. Keuntungan merupakan inti dari dunia bisnis dan itu merupakan suatu hal yang wajar. Maka, kita banyak melihat pelaku industri yang hanya mementingkan bagaimana menghasilkan keuntungan sebanyakbanyaknya tanpa melakukan upaya untuk melestarikan lingkungan. Padahal dengan melestarikan lingkungan, mereka justru akan memperoleh keuntungan yang lebih, terutama dari sisi kesehatan, kenyamanan, disamping ketersediaan sumber daya yang lebih terjamin kelangsungannya. (Wibisono, 2007 dalam Aryani dan Amanah, 2014).

b. People (Masyarakat), di sini perusahaan dituntut untuk memiliki kepedulian terhadap manusia. Hal tersebut berkaitan dengan praktikpraktik bisnis yang adil dan 
menguntungkan terhadap pekerja dan masyarakat dan daerah di mana sebuah perusahaan menjalankan bisnisnya. Serta berkomitmen untuk memperlakukan karyawan dengan cara yang etis dan adil, dan memberikan kompensasi yang adil. Secara konkret, pada bagian ini perusahaan akan membayar gaji yang adil untuk para pekerjanya, akan menjaga lingkungan kerja yang aman dan jam kerja ditoleransi, perusahaan dalam hal ini hadir untuk sosial mereka. People merupakan suatu hal yang nyata bahwa masyarakat sekitar perusahaan merupakan salah satu stakeholder penting bagi perusahaan, karena dukungan mereka sangat diperlukan bagi segala macam bentuk aktivitas perusahaan mulai dari keberadaan, kelangsungan hidup dan perkembangan perusahaan. Maka dari itu, perusahaan perlu berkomitmen untuk berupaya memberikan manfaat sebesar-besarnya kepada masyarakat. Selain itu juga perlu disadari bahwa aktivitas operasi perusahaan berpotensi memberikan dampak kepada masyarakat sekitar. Karenanya pula perusahaan perlu untuk melakukan berbagai kegiatan yang menyentuh kebutuhan masyarakat. Intinya, apabila perusahaan tetap ingin eksis perusahaan harus menyertakan pula laporan tanggung jawab yang bersifat sosial. (Wibisono, 2007 dalam Aryani dan Amanah, 2014).

c. Profit (Keuntungan), sebagai pilar Triple Bottom Line merupakan dampak ekonomi yang ditimbulkan dari keberadaan perusahaan. Nilai ekonomi yang ditimbulkan oleh organisasi setelah dikurangi semua biaya yang terjadi dalam aktivitas perusahaan. Keuntungan sendiri pada hakekatnya digunakan untuk menjamin kelangsungan hidup perusahaan. Untuk dapat meningkatkan pencapaian keuntungan dalam sebuah perusahaan yaitu dengan cara meningkatkan produktivitas, melakukan kegiatan efisiensi biaya dan yang paling penting perhatian terhadap segala sesuatu yang berhubungan dengan perusahaan, baik itu lingkungan sosial maupun lingkungan alam sebagai tempat berdirinya perusahaan, dengan demikian bahwa perusahaan akan memiliki keunggulan kompetitif yang dapat memberikan nilai tambah semaksimal mungkin. Profit merupakan unsur terpenting dan menjadi tujuan utama dari sebuah kegiatan usaha. Tidak aneh jika tujuan utama dari keseluruhan perusahaan adalah mengejar profit atau mendongkrak harga saham setinggitingginya, baik secara langsung maupun tidak langsung. Profit sendiri merupakan pendapatan yang dapat digunakan untuk menjamin kelangsungan hidup perusahaan. Sedangkan aktivitas yang dapat dilakukan untuk mendongkrak profit antara lain dengan meningkatkan produktivitas dan melakukan efisiensi biaya, sehingga perusahaan mempunyai keunggulan kompetitif dengan perusahaan lain dan dapat memberikan nilai tambah semaksimal mungkin (Wibisono, 2007 dalam Aryani dan Amanah, 2014).

Pemerintah telah membuat regulasi berkaitan dengan masalah lingkungan. Adapun regulasi tersebut 
Invoice: Jurnal Ilmu Akuntansi

p-ISSN: 2714-6359 e-ISSN: 2714-6340

Vol.2 Nomor 2 September 2020

terdapat dalam undang-undang No. 40 tahun 2007 tentang perseroan terbatas dan peraturan Bank Indonesia No. 7/2/PBI/2005 tentang penetapan peringkat kualitas aktiva bagi bank umum (Kusumaningtias, 2013). Selain itu, pemerintah Indonesia melalui Kementrian Negara Lingkungan Hidup menetapkan Peraturan Menteri Lingkungan Hidup Republik Indonesia Nomor 6 Tahun 2013 Tentang Program Penilaian Peringkat kinerja lingkungan perusahaan dalam Pengelolaan Lingkungan Hidup, telah melakukan pemeringkatan environmental performance perusahaan melalui suatu program yang dinamakan program for pollution control, evaluation and rating atau PROPER (Burhany, 2014).

\subsection{Rumah Sakit}

Rumah Sakit adalah sarana upaya kesehatan yang menyelengarakan kegiatan pelayanan kesehatan/medis yang bersifat preventif, kuratif, promotif, dan rehabilitatif (Permenkes RI Nomor: 986/Per/XI/1992; Sutrisnowati, 2004). Menurut WHO, Rumah Sakit adalah institusi yang merupakan bagian integral dari organisasi kesehatan dan organisasi sosial, berfungsi menyediakan pelayanan kesehatan yang lengkap, baik kuratif maupun preventif bagi pasien, rawat jalan dan rawat inap, kegiatan pelayanan medis, serta perawatan. Institusi pelayanan ini juga berfungsi sebagai latihan personil dan riset kesehatan.

Kementrian Kesehatan Republik Indonesia mendefinisikan Rumah Sakit sektor publik sebagai Rumah Sakit yang diselenggarakan oleh pemerintah dan swasta non-profit, meliputi: Rumah Sakit yang diselenggarakan oleh Kementrian Kesehatan Pemda Provinsi, Pemda Kabupaten, Pemda Kota, Kementrian lain, TNI, POLRI, dan Swasta non-profit. Pelayanan RS merupakan bagian yang tidak terpisah dari sistem pelayanan kesehatan pada umumnya (Aswar, 1998).

Jacobalis (1990) kualitas pelayanan kesehatan Rumah Sakit dapat diuraikan dari beberapa aspek, diantaranya aspek klinis, efisiensi dan efektivitas, keselamatan pasien, kepuasan pasien yang menyangkut kepuasan fisik, mental dan sosial pasien terhadap lingkungan Rumah Sakit, kebersihan, kenyamanan, kecepatan pelayanan, keramahan, perhatian, biaya yang diperlukan dan sebagainya.

\subsection{Akuntansi Lingkungan dalam Aktivitas Operasi Rumah Sakit}

Akuntansi Lingkungan merupakan salah satu bentuk kontribusi dan tanggung jawab Rumah Sakit terhadap sosial-lingkungan, Penerapannya sangat perlu dilakukan mengingat dampak ekstemalitas yang ditimbulkan dari adanya kegiatan operasi Rumah Sakit sangat besar. Dengan konsep ini, pihak manajemen Rumah Sakit dapat menetapkan biaya atau tarif layanan yang lebih akurat untuk mengetahui break event point yang sebenanya. Meskipun sangat penting, konsep akuntansi lingkungan ini belum banyak dikenal di kalangan sektor publik. Sedangkan bagi organisasi sektor publik masih menjadi sesuatu yang baru. Namun bukan berarti konsep ini tidak dapat diterapkan untuk organisasi sektor publik seperti Rumah Sakit. Faktorfaktor yang berpengaruh terhadap penerapan akuntansi lingkungan dalam aktivitas operasi Rumah Sakit adalah sebagai berikut:

a. Faktor sosial-lingkungan 
Invoice: Jurnal Ilmu Akuntansi

p-ISSN: 2714-6359 e-ISSN: 2714-6340

Vol.2 Nomor 2 September 2020

Penerapan akuntansi lingkungan di Rumah Sakit dipengaruhi oleh adanya rasa tanggung jawab sosial dan lingkungan dari pihak Rumah Sakit. Rasa tanggung jawab ini muncul karena pihak Rumah Sakit menyadari akan ekstemalitas dan dampak lingkungan yang timbul dari pelaksanaan aktivitas Rumah Sakit. Apalagi limbah yang dihasilkan oleh Rumah Sakit merupakan limbah yang berbahaya dan beracun.

b. Faktor nilai tambah

$$
\text { Rumah Sakit menerapkan }
$$
akuntansi lingkungan dengan tujuan untuk meningkatkan kinerja keuangan sehingga menciptakan nilai tambah bagi Rumah Sakit. Nilai tambah tersebut dapat diperoleh melalut image positif yang diciptakan melalui penerapan akuntansi lingkungan. Rumah Sakit yang menerapkan akuntansi lingkungan dapat memunculkan pelaksanaannya dalam laporan keuangan yang dapat diakses oleh semua pihak, dengan demikian, masyarakat luas akan mengetahui bahwa Rumah Sakit tersebut peduliakan kelestarian lingkungan dan kepercayaan masyarakat semakin meningkat karena Rumah Sakit menerapkan akuntansi lingkungan sebagai bentuk pertanggungjawaban dan transparansi kepada masyarakat atas pencemaran dan limbah yang dihasilkan oleh Rumah Sakit. Hingga saat ini, belum banyak organisasi swasta maupun publik yang menerapkan akuntansi lingkungan sebagai bagian dari usahanya karena manfaat dari penerapan akuntansi lingkungan dirasa tidak sebanding dengan biaya yang dikeluarkan. Aktivitas CSR dianggap tidak membertingkat pengembalian yang sepadan sehingga manajer lebih suka menginvestasikan dananya untuk hal yang lebih pasti demi keberlanjutan usahanya.

c. Faktor hukum

Aturan hukum yang mengatur penerapan akuntansi lingkungan di Rumah Sakit sektor publik di Indonesia saat ini belum ada, namun penerapan akuntansi lingkungan pada perusahaan swasta diatur dalam PP No. 47 Tahun 2012 yang merupakan tindak lanjut dari UU Perseroan Terbatas No. 40 Tahun 2007. Dalam undang-undang disebutkan bahwa setiap perseroan mempunyai tanggung jawab sosial dan lingkungan yang menjalankan usahanya di bidang yang berkaitan dengan sumber daya alam (Lindrianasari, 2007). Rumah Sakit juga menghasilkan berbagai macam limbah, untuk itu perlu dibuat aturan yang mengikat agar Rumah Sakit menerapkan akuntansi lingkungan karena kuantitas limbah yang dihasilkan dari aktivitas operasi Rumah Sakit cukup banyak. Peran regulasi sebaiknya diperkuat dengan peraturan daerah. Adanya peraturan daerahdapat dimaksimalkan penerapan akuntansi lingkungan karena pemerintah daerah dapat mengontrol secara langsung Rumah Sakit yang berada di wilayahnya serta meningkatkan sosialisasi kepada Rumah Sakit akan pentingnya penerapan akuntansi lingkungan (Niar dan yeni, 2012).

d. Komitmen Para Pelaku Rumah Sakit

Penerapan konsep ini, peran semua pihak Rumah Sakit sangat diperlukan. Diperlukan komitmen yang kuat dari semua pihak Rumah Sakit demi suksesnya penerapan semangat akuntansi lingkungan ini. 
Invoice: Jurnal Ilmu Akuntansi

p-ISSN: 2714-6359 e-ISSN: 2714-6340

Vol.2 Nomor 2 September 2020

\section{Kerangka Pemikiran}

Kerangka pemikiran

menurut Sekaran (2002) adalah jaringan asosiasi yang disusun, dijelaskan, dan dielaborasi, secara logis antar variable yang dianggap relevan pada situasi masalah dan diidentifikasi melalui proses wawancara, pengamatan dan dokumentasi. Secara lengkap kerangka fikir penelitian ini disajikan sebagai berikut:

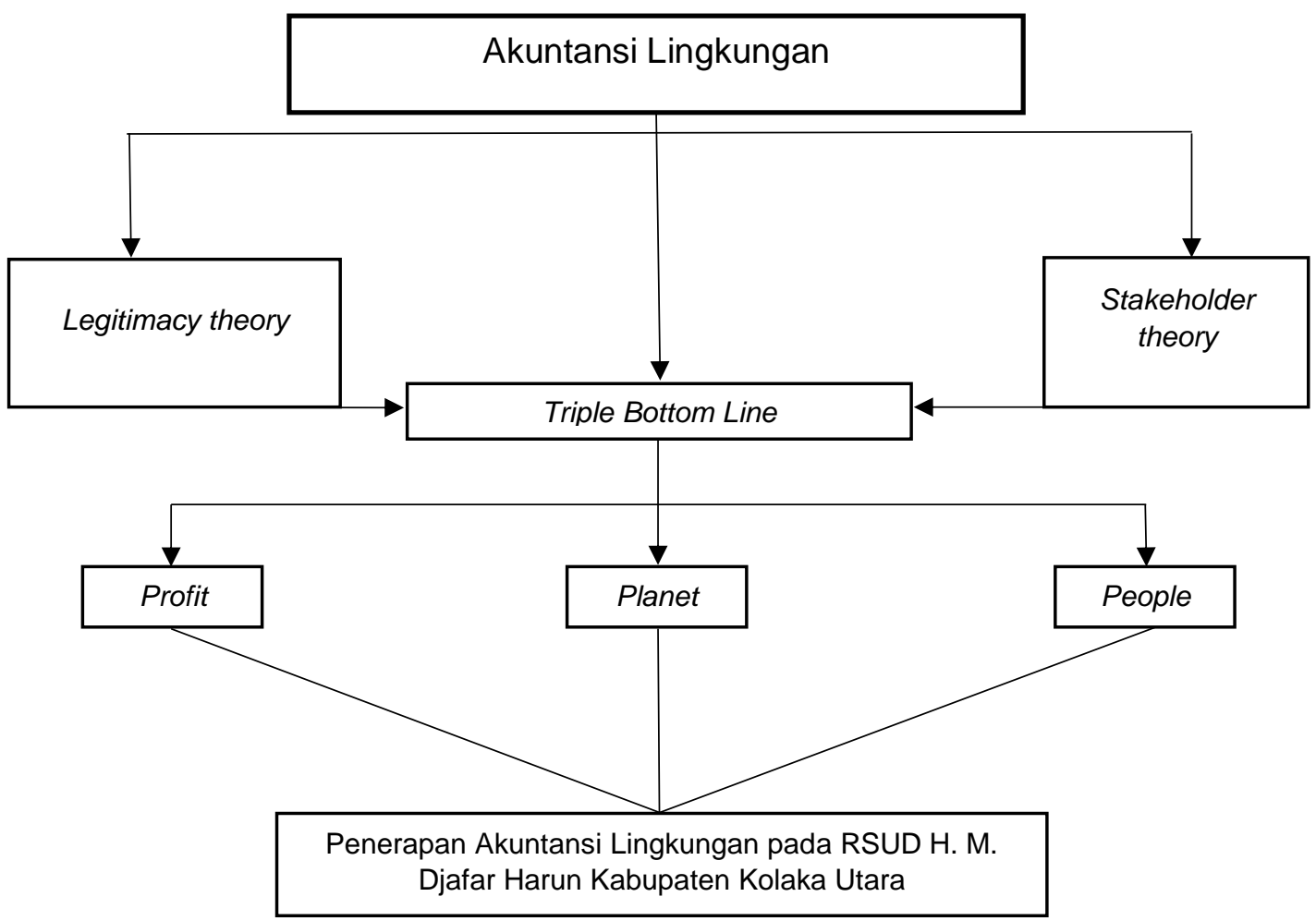

Gambar 1 Kerangka Pemikiran 
Invoice: Jurnal Ilmu Akuntansi

p-ISSN: 2714-6359 e-ISSN: 2714-6340

Vol.2 Nomor 2 September 2020

\begin{tabular}{lrllr}
\hline \hline \multicolumn{1}{c}{ Kerangka } & pemikiran dalam & pembahasan mengenai & penerapan \\
penelitian ini disusun dengan adanya & akuntansi lingkungan kemudian \\
kesadaran masyarakat terhadap & dikaitkan dengan penerapan akuntansi \\
permasalahan lingkungan yang & lingkungan pada Rumah Sakit Umum \\
ditimbulkan oleh perusahaan, dari hal & Daerah (RSUD) H. M. Djafar Harun \\
tersebut akuntansi lingkungan yang & Kabupaten Kolaka Utara yang didukung \\
menilai biaya dan manfaat dari sebuah & dengan teori Triple Bottom Line.
\end{tabular}
kegiatan lingkungan untuk mengurangi dampak kerusakan lingkungan dari perusahaan. Triple bottom line juga dijelaskan bahwa perusahaan tidak lagi memandang terhadap satu aspek saja dalam hal ini profit, namun perusahaan sudah mengacu pada tiga aspek yaitu profit, planet dan people.

Hal ini disebutkan bahwa perusahaan harus memiliki kepedulian terhadap manusia dan alam yang ada disekitarnya dengan mengeluarkan biaya dari sebuah kegiatan lingkungan perusahaan. Oleh kerena, itu legitimasi organisasi dapat dilihat sebagai sesuatu yang diberikan masyarakat kepada perusahaan dan sesuatu yang diinginkan atau dicari dari masyarakat, serta teori stakeholder sebagai informasi tanggung jawab sosial dan lingkungan untuk mendapatkan dukungan dari para pemangku kepentingan. Hal ini ditunjukkan dengan triple bottom line yang dilakukan oleh perusahaan sebagai wujud legitimasi serta pengungkapan informasi terhadap stakeholder, dengan demikian masyarakat dan pemangku kepentingan lainnya dapat ikut serta dalam mewujudkan pembangunan berkelanjutan yang dijabarkan dengan perbaikan kualitas hidup yang sesuai dengan daya dukung lingkungan, jika lingkungan sudah lestari, masyarakat berdaya maka profit atau keuntungan akan didapatkan sebagai feedback dari usaha yang telah dilakukan. Dari penjelasan landasan teori dalam

\section{METODE PENELITIAN}

\subsection{Model Analisis Data}

Jenis penelitian yang digunakan adalah penelitian kualitatif deskriptif. Penggunaan metode kualitatif dengan pendekatan deskriptif didasarkan atas anggapan bahwa peneliti dapat memaparkan dan menjawab pertanyaan yang ada di rumusan masalah mengenai penerapan akuntansi lingkungan berdasarkan triple bottom line pada RSUD H. M. Djafar Harun kabupaten kolaka utara.

Teknik analisis data yang digunakan dalam penelitian ini adalah analisis data kualitatif, mengikuti konsep yang diberikan Miles dan Huberman yaitu suatu aktivitas yang meliputi reduksi data, penyajian data, dan penarikan kesimpulan. Berikut merupakan penjelasan dari tahapan-tahapan tersebut:

\section{Reduksi Data}

Reduksi data merujuk pada proses pemilihan, pemfokusan, penyederhanaan, abstraksi, dan pentransformasian "data mentah" yang terjadi dalam catatan-catatan lapangan tertulis. Mereduksi data berarti merangkum, memilih hal-hal yang pokok, memfokuskan pada hal-hal yang penting, dicari tema dan polanya. Dalam hal ini, ketika peneliti memperoleh data dari lapangan dengan jumlah yang cukup banyak. Maka perlu segera dilakukan analisis data melalui reduksi data. 
Invoice: Jurnal Ilmu Akuntansi

p-ISSN: 2714-6359 e-ISSN: 2714-6340

Vol.2 Nomor 2 September 2020

Adapun hasil dari mereduksi data, peneliti telah memfokuskan pada bidang penerapan akuntansi lingkungan pada RSUD H. M. Djafar Harun Kabupaten Kolaka Utara. Hal ini dilakukan peneliti dengan mengamati serta meninjau kembali hasil wawancara yang akan dilakukan dengan pihak Rumah Sakit dan orang-orang yang bersangkutan dengan pelaksanaan penerapan akuntansi lingkungan.

\section{Penyajian Data}

Setelah data direduksi, selanjutnya peneliti mendisplaykan data yang berarti mengorganisir data, menyusun data dalam suatu pola hubungan sehingga semakin mudah difahami. Dalam hal ini, peneliti memfokuskan pada beberapa penerapan akuntansi lingkungan pada RSUD H. M. Djafar Harun Kabupaten Kolaka Utara berdasarkan teori triple bottom line yang di mana terdapat tiga indikator di dalamnya yaitu planet, people, dan profit. Dengan demikian, hasil dari data display ini mampu memudahkan peneliti dalam upaya pemaparan dan penegasan kesimpulan.

3. Penarikan Kesimpulan

Langkah ketiga dalam analisis data kualitatif menurut Miles dan Huberman adalah penarikan kesimpulan. Dalam hal ini, peneliti berusaha dan berharap kesimpulan yang dicapai mampu menjawab rumusan masalah yang telah dirumuskan sejak awal yaitu yang berkaitan dengan penerapan akuntansi lingkungan pada RSUD H. M. Djafar Harun Kabupaten Kolaka Utara.

\subsection{Pengujian Keabsahan Data}

Pemeriksaan terhadap keabsahan data pada dasarnya, selain digunakan untuk menyanggah balik apa yang dituduhkan kepada penelitian kualitatif yang mengatakan tidak ilmiah, juga merupakan sebagai unsur yang tidak terpisahkan dari tubuh pengetahuan penelitian kualitatif. Keabsahan data merupakan konsep penting yang diperbaharui dari konsep kesahihan (validitas) dan keandalan (realibilitas) selain itu, keabsahan data adalah bahwa setiap keadaan harus memenuhi: mendemonstrasikan nilai yang benar, menyediakan dasar agar hal itu dapat diterapkan, memperbolehkan keputusan luar yang dapat dibuat tentang akuntansi lingkungan.

Teknik yang digunakan adalah triangulasi yang artinya pemeriksaan keabsahan data yang menggunakan sesuatu yang lain diluar data itu untuk keperluan pengecekan atau sebagian perbandingan terhadap data itu. Jadi triangulasi merupakan cara terbaik untuk menghilangkan perbedaanperbedaan konstruksi kenyataan yang ada dalam konteks suatu studi sewaktu mengumpulkan data tentang berbagai kejadian dan hubungan dariberbagai pandangan. Maksud dari triangulasi disini adalah data wawancara diperiksa dalam keabsahan data, kemudian dibandingkan dengan hasil pengumpulan data yang lain, seperti observasi dan dokumentasi. Adapun langkah-langkah yang ditempuh dalam tahap triangulasi ini adalah:

1. Triangulasi sumber data adalah menggali kebenaran informasi tertentu melalui berbagai metode dan sumber perolehan data. Peneliti melakukan pengecekan tentang hasil dari pengamatan wawancara, maupun hasil data yang diperoleh dengan cara lain (observasi dan dokumen). Pengecekan dilakukan kepada pihakpihak yang terlibat dalam penerapan 
akuntansi lingkungn pada RSUD H. M. Djafar Harun Kolaka Utara.

2. Triangulasi Teori. Hasil akhir penelitian kualitatif berupa sebuah rumusan informasi. Informasi tersebut selanjutnya dibandingkan dengan persfektif teori yang relevan untuk menghindari bias individual peneliti atas temuan atau kesimpulan yang dihasilkan. Selain itu, triangulasi teori dapat meningkatkan kedalaman pemahaman asalkan peneliti mampu menggali pengetahuan teoritik secara mendalam atas hasil analisis data yang telah diperoleh.

\section{HASIL DAN PEMBAHASAN}

\subsection{Deskripsi Hasil Penelitian}

Pendekatan penelitian yang digunakan dalam penelitian adalah kualitatif deskriptif karena dalam penelitian ini menghasilkan kesimpulan berupa data yang menggambarkan secara rinci, bukan data yang berupa angka-angka. Hal ini karena pendekatan kualitatif sebagai prosedur penelitian yang menghasilkan data deskriptif berupa kata-kata tertulis atau lisan dari orang-orang dan perilaku yang diamati.
Penelitian ini akan menjelaskan bahwa bagaimana penerapan akuntansi lingkungan berdasarkan triple bottom line pada RSUD H. M. Djafar Harun Kabupaten Kolaka Utara. Biaya-biaya lingkungan (biaya dalam aktivitas sanitasi) yang dikeluarkan oleh rumah sakit secara umum yaitu Aktivitas Limbah Cair, Aktivitas Limbah Padat, dan Penyehatan Air Bersih. Pada triple bottom line penelitian ini dikaji berdasarkan Profit, People, dan Planet.

Berdasarkan visi dan misi rumah sakit dalam mengelolah limbah, pada penelitian ini dijelaskan juga Sanitasi Lingkungan, Data Kualitatif Sehubungan dengan Pengelolaan Limbah, Limbah Rumah Sakit, dan Penanganan Limbah. Dengan demikian, RSUD H. M. Djafar Harun Kabupaten Kolaka Utara akan senantiasa berupaya melaksanakan fungsinya semaksimal mungkin dengan terus berusaha mengadakan perbaikan dan peningkatan sarana dan prasarana serta kinerja petugasnya. Berdasarkan penjelasan tersebut, berikut adalah informan yang di wawancarai pada penelitian ini:

Tabel 1 Data Informan

\begin{tabular}{|l|l|l|}
\hline No & \multicolumn{1}{|c|}{ Nama } & \multicolumn{1}{c|}{ Jabatan } \\
\hline 1 & RM & Bagian Keuangan \\
\hline 2 & AS & Bagian Pengawasan dan Pengendalian \\
\hline 3 & TM, AM. KL & Bagian Penunjang dan Pelayanan \\
\hline 4 & NB, SKM & Koordinator Cleaning Service \\
\hline 5 & Ibu KS & Warga Desa Tojabi (Masyarakat) \\
\hline 6 & Ibu NR & Warga Desa Tojabi (Masyarakat) \\
\hline 7 & Ibu SN & Warga Desa Tojabi (Masyarakat) \\
\hline 8 & Ibu LN & Warga Desa Tojabi (Masyarakat) \\
\hline
\end{tabular}


Invoice: Jurnal Ilmu Akuntansi

p-ISSN: 2714-6359 e-ISSN: 2714-6340

Vol.2 Nomor 2 September 2020

\subsection{Penerapan Akuntansi Lingkungan}

a. Deskripsi Elemen

RSUD H. M. Djafar Harun Kabupaten

Kolaka Utara sudah berupaya dalam memperbaiki kualitas lingkungan secara berkelanjutan. Bentuk kepedulian rumah sakit terhadap lingkungan direalisasikan dengan cara menjaga kebersihan dan kesehatan lingkungan rumah sakit, melakukan pengelolaan limbah baik limbah medis maupun limbah non medis sebelum dilakukan pembuangan, serta selalu berusaha untuk mematuhi peraturan dan perundangan lingkungan sesuai dengan arahan Dinas Kesehatan RI dan mengembangkan, mengkaji, dan memelihara kebijakan lingkungan. Hal ini sesuai dengan penyampaian Ibu NB, selaku bagian koordinasi cleaning service, bahwa:

"Hal utama dilakukannya pengujian ini adalah untuk mencegah penularan penyakit. Jangan sampai pasien yang datang karena sakit flu pulang menderita sakit diare, karena itu berarti terjadi suatu kesalahan di dalam rumah sakit."

RSUD H. M. Djafar Harun Kabupaten Kolaka Utara sudah memiliki IPAL (Instalasi Pengelolaan Air Limbah), yang fungsinya mengolah limbah cair supaya tidak berbahaya bagi lingkungan sekitar. IPAL yang dimiliki rumah sakit adalah IPAL yang dalam pengoperasiannya menggunakan pemanfaatan lumpur aktif (activated sludge), yang merupakan salah satu upaya penanganan limbah cair dengan cara biologis. Rumah sakit telah mengadakan peningkatan kualitas, yaitu dengan merombak dan memperluas IPAL, yang tujuannya adalah untuk menaikkan nilai kegunaan IPAL agar beroperasi lebih maksimal dengan daya tamping limbah cair yang lebih besar.
Biaya yang dikeluarkan untuk pembangunan IPAL ini adalah sebesar \pm Rp 350.000.000,00. Luas bangunan IPAL yang terdapat di RSUD H. M. Djafar Harun Kabupaten Kolaka Utara saat ini adalah 8 x 15 meter dengan kedalaman 4 meter, yang lokasinya berada di basement gedung rumah sakit. Pemilihan lokasi basement dilakukan karena luas bangunan rumah sakit tidak memungkinkan serta sebagai bentuk pemanfaatan ruang. Aktivitas dari IPAL kemudian dipantau melalui lubang got. RSUD H. M. Djafar Harun Kabupaten Kolaka Utara memiliki dua pegawai IPAL, yang merupakan pegawai sanitasi juga sekaligus memantau aktivitas limbah lainnya.

Pengelolaan limbah padat (dalam hal ini pembuangan dan pembakaran limbah padat) pihak rumah sakit bekerjasama dengan pihak ketiga, untuk penanganan terhadap limbah padat B3 medis dan B3 non medis. Dalam pembakaran limbah padat B3 ini rumah sakit mengeluarkan biaya sekitar $\mathrm{Rp}$ $10.000 / \mathrm{kg}$. Untuk biaya yang dikeluarkan oleh rumah sakit untuk transportasi pengangkutan dan pembakaran limbah padat B3 medis dan B3 non medis, rumah sakit mengeluarkan biaya sekitar Rp 10.000.000 - Rp 20.000.000 per bulan. Kemudian untuk penanganan limbah domestik, rumah sakit juga melakukan kerjasama dengan warga sekitar. Biaya yang dikeluarkan rumah sakit untuk limbah domestik ini adalah Rp 150.000 per bulan.

Biaya lingkungan yang terdapat di RSUD H. M. Djafar Harun Kabupaten Kolaka Utara terkait pada biaya yang dikeluarkan dalam aktivitas sanitasi rumah sakit sekaligus yang termasuk didalamnya yaitu pengelolaan limbah. 
Biaya terbesar yang dikeluarkan lebih kepada pengelolaan limbah baik itu limbah cair maupun limbah padat. Untuk limbah cair dilakukan melalui investasi jangka panjang mesin IPAL. Sedangkan untuk limbah padat pihak rumah sakit melakukan kerjasama dengan pihak ketiga sebagaimana yang sudah dijelaskan.

Biaya-biaya lingkungan (biaya dalam aktivitas sanitasi) yang dikeluarkan oleh rumah sakit kemudian secara umum dikelompokkan dan disajikan oleh peneliti dalam perincian sebagai berikut:

1) Aktivitas Limbah Cair :

a) Biaya Gaji Pengelola

b) Lingkungan dan IPAL

c) Biaya Pemeliharaan IPAL

d) Biaya Pengujian Limbah

e) Biaya Sedot WC

f) Biaya Semprot Saluran

2) Aktivitas Limbah Padat:

a) Biaya Transportasi Sampah Medis

b) Biaya Transportasi Sampah Non Medis

c) Biaya Bakar Sampah Medis

d) Biaya Retribusi Sampah (Domestik)

e) Biaya Kebersihan Lingkungan

3) Penyehatan Air Bersih yaitu menggunakan Biaya Uji Air Bersih Pengendalian Vektor \& Binatang Pengganggu dengan menggunakan Biaya Pembasmian Serangga dan Binatang Pengganggu

Penjelasan dari biaya-biaya tersebut dapat dijelaskan yaitu sebagai berikut:

1) Biaya Gaji Pengelola Lingkungan dan IPAL merupakan biaya gaji yang dikeluarkan untuk pegawai pengelola lingkungan yang sekaligus sebagai pengelola IPAL.

2) Biaya Pemeliharaan IPAL merupakan biaya yang dikeluarkan untuk pemeliharaan IPAL seperti biaya pergantian spoll blower, biaya servis mesin, dan lain-lain.

3) Biaya Pengujian Limbah merupakan biaya yang dikeluarkan untuk menguji kadar zat yang terkandung dalam hasil pengolahan limbah. Biaya Pengujian Limbah dalam RSUD H. M. Djafar Harun Kabupaten Kolaka Utara terbagi menjadi Biaya Uji Limbah Cair (lumpur dan lemak) dan Biaya Uji Lab. Mikroba.

4) Biaya Sedot WC merupakan biaya yang dikeluarkan untuk menyedot apabila terjadi penumpukan lumpur dan minyak lemak secara berlebih (atau terjadinya pulk pada lumpur dan minyak lemak).

5) Biaya Semprot Saluran adalah biaya yang dikeluarkan untuk menyemprot saluran dalam IPAL yang tersumbat.

6) Biaya Transportasi Sampah Medis dan Non medis, Biaya Bakar Sampah Medis, serta Biaya Retribusi Sampah (Domestik) merupakan biaya yang dikeluarkan untuk penanganan sampah padat. Biaya ini berhubungan dengan pihak ketiga.

7) Biaya Kebersihan Lingkungan yang ada di rumah sakit lebih berkaitan dengan kebersihan lingkungan rumah sakit, contohnya adalah biaya gaji untuk cleanning service.

8) Biaya Uji Air Bersih dilakukan untuk mengetahui kadar yang terkandung dalam air bersih di rumah sakit dan memastikan bahwa air aman untuk digunnakan.

9) Biaya Pembasmian Serangga dan Binatang Pengganggu, contohnya 
seperti biaya obat nyamuk dan biaya racun tikus.

RSUD H. M. Djafar Harun Kabupaten Kolaka Utara dalam memenuhi persyaratan kesehatan lingkungan mengadakan unit kerja yang khusus mengelola lingkungan yaitu Unit Sanitasi Lingkungan. Unit Sanitasi Lingkungan ini secara struktur organisasi berada dibawah pengawasan dari Sub Bagian Rumah Tangga. Kegiatan yang dilakukan oleh Sanitasi Lingkungan ini antara lain sebagai berikut:

1) Membuat dan menyusun program kerja pelayanan sanitasi.

2) Membuat Standar Prosedur Operasional (SPO) kegiatan sanitasi

3) Penyehatan air bersih

4) Pengelolaan Limbah Cair

5) Pengelolaan Limbah Padat Bahan Berbahaya dan Beracun (B3)

6) Pengelolaan Sampah Non Medis (Domestik)

7) Pengendalian Vektor dan Binatang Pengganggu

8) Pengawasan Kebersihan Lingkungan Rumah Sakit

9) Pemeriksaan Angka Kuman Ruangan

10) Pemeriksaan Lingkungan Fisik Ruangan

11) Sterilisasi Ruangan dan Alat Medis

12) Pengawasan Penyehatan Makanan dan Minuman

13) Penyehatan Linen

14) Membuat Laporan Keuangan Sanitasi

15) Membuat Laporan UKL UPL

\subsection{Implementasi Akuntansi} Lingkungan Berdasarkan Teori Triple Bottom Line

Rumah Sakit Rumah RSUD H. M. Djafar Harun Kabupaten Kolaka Utara menyadari dan meyakini bahwa ekonomi, sosial dan lingkungan merupakan bagian penting dari pembangunan berkelanjutan Rumah Sakit. Hal ini sesuai dengan teori Triple Bottom Line yang tidak hanya memperhatikan keuntungan Rumah Sakit saja tapi memperhatikan masyarakat dan lingkungan yang ada disekitar Rumah Sakit.

Penjelasan tersebut sesuai dengan Istilah teori Triple Bottom Line di populerkan pertama kali oleh John Elkington (1997) di dalam bukunya "Cannibals With forks, The Triple Bottom Line of Twentieth Century Business" memberi pandangan Rumah Sakit yang ingin berkelanjutan haruslah memperhatikan "3P". Selain mengejar keuntungan (profit), Rumah Sakit juga mesti memperhatikan dan terlibat pada pemenuhan kesejahteraan masyarakat (people) dan turut berkontribusi dalam menjaga kelestarian lingkungan (planet) (Armin, 2011: 15).

Teori ini menjadi salah satu latar belakang berdirinya RSUD H. M. Djafar Harun Kabupaten Kolaka Utara yang diungkapkan dalam laporan pengelolaan dan pemantauan RSUD H. M. Djafar Harun Kabupaten Kolaka Utara. Pembangunan berkelanjutan RSUD H. M. Djafar Harun Kabupaten Kolaka Utara tidak hanya dituntut untuk memperhatikan keuntungan ekonomi semata, namun juga memperhatikan aspek lainnya yakni aspek sosial dan aspek ekologi (laporan pengelolaan dan pemantauan RSUD H. M. Djafar Harun Kabupaten Kolaka Utara tahun 2013 h.4).

Menurut Nurfajriyah (2010:39) bahwa keseimbangan triple bottom line merupakan suatu upaya yang sungguhsungguh untuk bersinergi dengan tujuan pembangunan berkelanjutan yang secara 
Invoice: Jurnal Ilmu Akuntansi

p-ISSN: 2714-6359 e-ISSN: 2714-6340

Vol.2 Nomor 2 September 2020

konsisten mendorong keseimbangan ekonomi, sosial dan lingkungan. Idealnya, tentu saja Rumah Sakit melakukan seluruh kegiatan triple bottom line bagi para stakeholdernya. Namun, hal yang terpenting sebenarnya Rumah Sakit melakukan CSR dengan menekankan pada lingkungan dan penbangunan keberlanjutan (sustainable development).

Penelitian ini berfokus pada indikator Triple Bottom Line khusus aspek lingkungan. Namun, karena aspek lingkungan, ekonomi, sosial tidak bisa dipisahkan sebagaimana dikemukan oleh John Elkington dalamLako (2011: 65) bahwa agar bisnis Rumah Sakit bisa tumbuh secara berkelanjutan hanya ada satu pilihan, yaitu menyeleraskan pencapaian kinerja laba (profit) dengan kinerja sosial (people) dan kinerja lingkungan (planet) secara berkesinambungan, maka penulis menguraikan implementasi aspek-aspek sebagai berikut:

1) Lingkungan (Planet)

Pada Implementasi Akuntansi Lingkungan Berdasarkan Teori Triple Bottom Line berdasarkan aspek lingkungan, RSUD H. M. Djafar Harun Kabupaten Kolaka Utara dalam melakukan pengukuran menggunakan satuan moneter sebesar biaya yang dikeluarkan. Sesuai dengan yang diungkapkan oleh ibu RM, selaku bagian keuangan:

"Biaya dalam sanitasi lingkungan termasuk biaya limbah diukur menggunakan rupiah. Jumlahnya yaitu sesuai dengan yang telah dikeluarkan, berdasarkan rincian harga dan kesepakatan yang ada"
Sampai saat ini pengukuran terkait dengan biaya lingkungan belum ditetapkan standar pengukurannya. Kerangka Dasar Penyusunan Penyajian Laporan Keuangan (KDPPLK) paragraf 100 telah menentukan dasar pengukuran yang dapat digunakan, dasar pengukuran itu terbagi menjadi 4 (empat) pengukuran. Berikut ini disajikan perbandingan pengukuran RSUD $\mathrm{H}$. M. Djafar Harun Kabupaten Kolaka Utara dengan pengukuran yang telah ditetapkan Kerangka Dasar Penyusunan Penyajian Laporan Keuangan (KDPPLK) paragraf 100 yaitu sebagai berikut:

a) Biaya Historis: Aktiva dicatat sebesar pengeluaran kas (atau setara kas) yang dibayar atau sebesar nilai wajar dari imbalan (consideration) yang diberikan untuk memperoleh aktiva tersebut pada saat perolehan.

b) Biaya Kini: Aktiva dinilai dalam jumlah kas (atau setara kas) yang seharusnya dibayar bila aktiva yang sama atau setara aktiva diperoleh sekarang.

c) Nilai Realisasi atau Penyelesaian: Aktiva dinyatakan dalam jumlah kas (atau setara kas) yang dapat diperoleh sekarang dengan menjual aktiva dalam pelepasan normal (orderly disposal).

d) Nilai Sekarang: Aktiva dinyatakan sebesar arus kas masuk bersih di masa depan yang didiskontokan ke nilai sekarang dari pos yang diharapkan dapat memberikan hasil dalam pelaksanaan usaha normal.

Berdasarkan pernyataan tersebut, dapat diketahui bahwa pengukuran yang dilakukan oleh RSUD H. M. Djafar Harun Kabupaten Kolaka Utara telah memenuhi unsur pengukuran pada KDPPLK 
Invoice: Jurnal Ilmu Akuntansi

p-ISSN: 2714-6359 e-ISSN: 2714-6340

Vol.2 Nomor 2 September 2020

paragraf.100, yaitu pengukuran dengan menggunakan biaya historis.

Berdasarkan penjelasan tersebut, menurut renja 2019, adapun program prioritas RSUD H.M. Djafar Harun Kabupaten Kolaka Utara yaitu dengan melakukan Program pengadaan peralatan/bahan medis dan non medis melalui pembelian, penyewaan, dan konsinyasi sesuai dengan alur yang benar, Pemilihan Pemasok barang nonmedis yang benar, dan Proses pemeliharaan dan perbaikan pasca proses pengadaan.

Pada proses pemeliharaan barang medis maupun non medis, RSUD H. M.
Djafar Harun Kabupaten Kolaka Utara melakukan uji labolatorium pengujian dan kalibrasi, serta melakukan Uji Mikrobiologi untuk mengetahui kadar mikroba dalam limbah cair yang telah diproses melalui IPAL. Hasil dari pengujian tersebut adalah kadar baku mutu limbah cair selalu dibawah batas maksimum yang diperbolehkan sesuai dengan standar baku mutu limbah cair, yang artinya bahwa baku mutu limbah cair dalam keadaan baik. Salah satu laporan hasil uji terhadap limbah cair yaitu sebagai berikut:

Tabel 2 Laporan Hasil Uji

\begin{tabular}{|c|c|c|c|c|}
\hline No & Parameter & Satuan & Hasil & $\begin{array}{c}\text { Kadar Paling Banyak } \\
\text { (mg/L) }\end{array}$ \\
\hline 1 & Suhu & ${ }^{\circ} \mathrm{C}$ & 26,7 & 30 \\
\hline 2 & Zat padat tersuspensi & $\mathrm{mg} / \mathrm{L}$ & 10 & 30 \\
\hline 3 & TDS & $\mathrm{mg} / \mathrm{L}$ & 685 & 2000 \\
\hline 4 & BOD5 & $\mathrm{mg} / \mathrm{L}$ & 12,11 & 30 \\
\hline 5 & COD & $\mathrm{mg} / \mathrm{L}$ & 51,36 & 80 \\
\hline 6 & Amonia Bebas & $\mathrm{mg} / \mathrm{L}$ & 0,030 & 5 \\
\hline 7 & Deterjen (MBAS) & $\mathrm{mg} / \mathrm{L}$ & 0,276 & 0,5 \\
\hline 8 & Fenol & $\mathrm{mg} / \mathrm{L}$ & 0,017 & $6-9$ \\
\hline 9 & Ph & $\mathrm{mg} / \mathrm{L}$ & 7,22 & \\
\hline
\end{tabular}

Sumber: RSUD H. M. Djafar Harun Kabupaten Kolaka Utara

Pengujian dilakukan selama sebulan sekali. Pengujian ini dilakukan bertujuan untuk mengetahui kadar zat yang terkandung dalam limbah cair sehingga dapat dipastikan aman bagi lingkungan. Selain itu tujuan utama dari pengujian ini adalah untuk mencegah penularan penyakit di dalam rumah sakit.

Berdasarkan penjelasan tersebut, pada implementasi lingkungan, RSUD $\mathrm{H}$. M. Djafar Harun Kabupaten Kolaka Utara telah menggunakan pengukuran aturan Kerangka Dasar Penyusunan Penyajian
Laporan Keuangan (KDPPLK), program renja 2019 yang fokus terhadap lingkungan, dan pelaksanaan yang menggunakan uji laboratorium terhadap barang medis dan non medis, maka dapat disimpulkan RSUD H. M. Djafar Harun Kabupaten Kolaka Utara telah melakukan implementasi akuntansi lingkungan berdasarkan triple bottom line berdasarakan aspek lingkungan.

Hasil penelitian ini sejalan dengan pendapat Syuhada (2012:27) yang mengatakan Planet atau Lingkungan adalah sesuatu yang terkait dengan 
Invoice: Jurnal Ilmu Akuntansi

p-ISSN: 2714-6359 e-ISSN: 2714-6340

Vol.2 Nomor 2 September 2020

seluruh bidang dalam kehidupan manusia. Hubungan Rumah Sakit dengan lingkungan adalah hubungan sebab akibat, dimana jika Rumah Sakit merawat lingkungan maka lingkungan akan memberikan manfaat kepada Rumah Sakit. Sudah kewajiban Rumah Sakit untuk peduli terhadap lingkungan hidup dan berkelanjutan keragaman hayati. Misalnya, penghijauan lingkungan hidup, perbaikan pemukiman, serta pengembangan pariwisata (ekoturisme).

\section{2) Masyarakat (People)}

People atau masyarakat merupakan stakeholders yang sangat penting bagi Rumah Sakit, karena dukungan masyarakat sangat diperlukan bagi keberadaan, kelangsungan hidup, dan perkembangan Rumah Sakit. Maka dari itu Rumah Sakit perlu berkomitmen untuk berupaya memberikan manfaat sebesar-besarnya kepada masyarakat.

Berdasarkan laporan pelaksanaan corporate social responsibility RSUD H. M. Djafar Harun Kabupaten Kolaka Utara, telah melakukan berbagai kegiatan yang dapat menyentuh kebutuhan masyarakat yakni memberikan bantuan sarana ibadah dan bantuan kesehatan. Hal ini sejalan dengan apa yang diungkapkan oleh Pian Angling (2010: 34) bahwa operasi Rumah Sakit berpotensi memberi dampak kepada masyarakat. Oleh karena itu Rumah Sakit perlu untuk melakukan berbagai kegiatan yang dapat menyentuh kebutuhan masyarakat.

Selama tahun 2020, RSUD H. M. Djafar Harun Kabupaten Kolaka Utara telah menerima bantuan diantaranya adalah bantuan 60 alat pelindung diri (APD) dari PT Andromeda Mineral Persada (PT AMP) dan PT Ekasa Yad Resources (PT EYR).
Uraian tersebut diperkuat oleh informan yang diwawancara oleh peneliti. Peneliti melakukan wawancara mengenai bantuan-bantuan dari Rumah Sakit - Rumah Sakit, kepada Bapak TM bagian penunjang dan pelayanan kesehatan, dimana informan mengatakan sebagai berikut:

"Alhamdulillah untuk bantuan APD dari pemerintah, lembaga sosial dan dari pihak swasta saat ini stoknya sudah cukup. Untuk anggaran sendiri kami tersedia, hanya saja saat ini APD langka dan mobilisasi barangnya ke sini yang susah".

Dikatakan, meski APD stoknya cukup, namun pihaknya tetap harus waspada untuk menyediakan APD. Percepatan Penanganan Covid-19 Kolut ini juga meminta kepada masyarakat harus lebih sadar pentingnya pengunaan masker dan menjaga kebersihan lingkungan, serta lebih sering mencuci tangan dengan sabun untuk memotong mata rantai virus mematikan tersebut.

Pada renja 2019 disebutkan salah satu kegiatan rumah sakit adalah program promosi kesehatan dan pemberdayaan masyarakat dalam mewujudkan RSUD H. M. Djafar Harun sebagai rumah sakit mitra keluarga dengan melakukan proses memberdayakan Pasien, keluarga Pasien, sumber daya manusia Rumah Sakit, pengunjung Rumah Sakit, dan masyarakat sekitar Rumah Sakit untuk berperan serta aktif dalam proses asuhan untuk mendukung perubahan perilaku dan lingkungan serta menjaga dan meningkatkan kesehatan menuju pencapaian derajat kesehatan yang optimal. 
Invoice: Jurnal Ilmu Akuntansi

p-ISSN: 2714-6359 e-ISSN: 2714-6340

Vol.2 Nomor 2 September 2020

Berdasarkan penjelasan tersebut, program promosi ini juga berdampak besar bagi masyarakat sekitar rumah sakit yaitu selah satunya adalah Ibu KS selaku masyarakat disekitar rumah sakit yang mengungkapkan bahwa:

"hmm... kalau saya pribadi pernah merasakan de bantuan dari rumah sakit... seperti misalnya pernah diadakan perkumpulan seminar... bagus caranya menjelaskan... banyak kutau dari situ"

Berdasarkan penjelasan tersebut, Ibu KS telah mengikuti beberapa seminar yang diadakan RSUD H. M. Djafar Harun. Dari penjelasan tersebut, peneliti mengetahui bahwa seminar tersebut diadakan di depan kantor kepala desa. Namun masih ada beberapa masyarakat yang tidak sempat hadir dalam seminar tersebut. Hal ini dijelaskan oleh salah satu warga yaitu Ibu SN yang mengungkapkan bahwa:

"Kalau saya pribadi belum pernah merasakan bantuan... mungkin ada yang pernah merasakan de... kah saya sibuk $k a$ biasa..."

Berdasarkan penjelasan tersebut, Ibu SN menjelaskan tidak sempat hadir dikarenakan kesibukkannya maka dapat disimpulkan seminar yang dilakukan RSUD H. M. Djafar Harun telah diketahui sebelumnya oleh masyarakat.

Pada aspek masyarakat ini, RSUD H. M. Djafar Harun selalu berusaha menyediakan APD kepada masyarakat sekitar dengan selalu memperhatikan stok yang tersedia dan menghimpun bantuan dari komunitas daerah serta seminar yang dilakukan oleh RSUD H. M. Djafar Harun membahas mengenai perubahan perilaku yang seharusnya dilakukan pada saat pandemi serta menjaga dan meningkatkan kesehatan agar dapat mencapai derajat kesehatan yang optimal. Hal ini dilakukan untuk memberikan pengetahuan kepada masyarakat agar dapat menjaga diri apabila kondisi pandemi semakin memburuk. Berdasarkan penjelasan tersebut, RSUD H. M. Djafar Harun telah melakukan implementasi akuntansi lingkungan berdasarkan triplr bottom line berdasarkan aspek masyarakat.

Hasil penelitian tersebut, sejalan dengan teori menurut Wibisono, (2007) dalam Aryani dan Amanah, (2014) perusahaan dituntut untuk memiliki kepedulian terhadap manusia. Hal tersebut berkaitan dengan praktikpraktik bisnis yang adil dan menguntungkan terhadap pekerja dan masyarakat dan daerah di mana sebuah perusahaan menjalankan bisnisnya.

\section{3) Ekonomi (profit)}

Ekonomi menjadi tujuan utama dan terpenting dalam setiap kegiatan usaha. Aktivitas yang dapat ditempuh untuk mendongkrak profit antara lain dengan meningkatkan produktivitas dan melakukan efiisensi biaya. Peningkatan produktivitas bisa diperoleh dengan memperbaiki manajemen kerja mulai penyederhanaan proses, mengurangi aktivitas yang tidak efisien, menghemat waktu proses dan pelayanan. Sedangkan efisiensi biaya dapat tercapai jika Rumah Sakit menggunakan material sehemat mungkin dan memangkas biaya serendah mungkin.

Kontribusi Rumah Sakit dalam bidang ekonomi juga dapat ditunjukkan dengan peningkatan kesejehateraan terhadap masyarakat sekitar Rumah Sakit sebagaimana dikemukakan oleh Dwi Kartini (2009: 46) bahwa kesejahteraan untuk pihak internal harus 
Invoice: Jurnal Ilmu Akuntansi

p-ISSN: 2714-6359 e-ISSN: 2714-6340

Vol.2 Nomor 2 September 2020

dibarengi dengan kesejateraan untuk pihak eksternal (dalam hal ini masyarakat). Hal ini pun disadari oleh RSUD H. M. Djafar Harun Kabupaten Kolaka Utara dengan berkontribusi terhadap masyarakat dengan jalan menumbuhkembangkan pelayanan kesehatan di masyarakat sekitar.

$$
\text { RSUD H. M. Djafar Harun }
$$

Kabupaten Kolaka Utara membawa dampak yang sangat positif di bidang ekonomi, dalam hal ini menyerap tenaga kerja yang cukup banyak, sehingga dapat mengurangi pengangguaran yang hingga saat ini merupakan masalah nasional yang belum terpecahkan, meningkatkan nilai ekonomi tanah di lokasi tersebut, menumbuh kembangkan usaha-usaha di masyarakat sekitar. (Laporan Pengelolaan dan Pemantauan RSUD H. M. Djafar Harun Kabupaten Kolaka Utara hal. 4)

Melihat dari pernyataan tersebut dapat disimpulkan bahwa bukan hanya Rumah Sakit yang mendapatkan keuntungan tetapi masyarakat yang ada di sekitar kawasan mendapatkan keuntungan pula karena bisa bekerja dalam Rumah Sakit - Rumah Sakit kawasan tersebut. Hal tersebut sejalan dengan yang diungkapkan Ibu RM bagian keuangan, dari hasil wawancara sebagai berikut:

"Ya kalau menurut saya sih sudah menguntungkan karena dengan adanya kawasan ini, mereka yang tidak punya pekerjaan ya.....sudah punya"

Pernyataan tersebut sangat terkait dengan salah satu teori yang mendasari sebuah Rumah Sakit melakukan CSR yaitu, teori legitimasi. Pernyataan tersebut sejalan dengan apa yang diungkapkan Deegan et. al. yang menyatakan kontrak sosial yang berkaitan dengan license to operate, digunakan untuk menjelaskan tentang anggapan dari masyarakat mengenai bagaimana seharusnya sebuah Rumah Sakit beroperasi. Khususnya bila mengenai terancamnya hidup sebuah Rumah Sakit akibat masyarakat menganggap bahwa Rumah Sakit telah melanggar kontrak sosial. Kesimpulan yang dapat ditarik ialah Rumah Sakit Rumah Sakit di kawasan tersebut dalam melaksanakan CSR juga memberikan perhatian kepada seluruh pihak yang berkepentingan artinya Rumah SakitRumah Sakit di kawasan tersebut peduli kepada semua pihak yang berkepentingan untuk tetap menjamin terjaganya investasi sosial guna mendapatkan license to operate dari semua orang yang berkepentingan.

Berdasarkan penjelasan tersebut, ditegaskan juga oleh Ibu AS selaku bagian pengawasan dan pengendalian yang mengungkapkan bahwa:

"eee.... selalu ji itu de dijaga... soal sarana dan prasarana apalagi... seperti masing - masing klinik yang kita punya disini toh... itu selalu diawasi pelayanan kualitasnya... kami juga disini ada uji kompetensi bagi petugas kesehatan, jadi pastilah semua petugas kesehatan di rumah sakit ini sudah teruji dalam memberikan pelayanan... kah hal itu mi yang buat masyarakat percaya sama ini rumah sakit toh..."

Berdasarkan pernyataan tersebut, penjelasan yang diberikan oleh Ibu AS telah sesuai dengan program renja 2019 RSUD H. M. Djafar Harun Kabupaten Kolaka Utara sebagai berikut:

a) Program peningkatan sarana dan prasarana rumah sakit. Merupakan 
suatu cara menjaga sarana yaitu Klinik Penyakit Dalam, Klinik Anak, Klinik Bedah, dan Klinik Kebidanan dan Penyakit Kandungan. Serta prasarana yang dijaga yaitu ruang ibadah, toilet, tempat parkir, tempat sampah, serta fasilitas komunikasi dan informasi

b) Program pengembangan SDM tenaga medis, paramedic, penunjang medis dan manajemen rumah sakit yaitu dengan melakukan pembinaan dan pengawasan mutu tenaga kesehatan dilakukan melalui peningkatan komitmen dan koordinasi semua pemangku kepentingan dalam pengembangan tenaga kesehatan serta legislasi yang meliputi antara lain sertifikasi melalui uji kompetensi, registrasi, perizinan (licensing), dan hak-hak tenaga kesehatan.

Berdasarkan program tersebut yaitu dengan mejaga sarana dan prasarana serta menekan pengangguran dan memberikan pengalaman kepada tenaga kesahatan dapat membuat kinerja rumah sakit meningkat sehingga dapat meningkatkan profit pada rumah sakit, maka dapat dikatakan RSUD H. M. Djafar Harun Kabupaten Kolaka Utara telah melakukan implementasi akuntansi lingkungan berdasarkan triple bottom line berdasarkan aspek ekonomi.

Hasil penelitian tersebut, telah sesuai dengan teori menurut Wibisono, (2007) dalam Aryani dan Amanah, (2014) yang mengatakan bahwa untuk dapat meningkatkan pencapaian keuntungan dalam sebuah perusahaan yaitu dengan cara meningkatkan produktivitas.

\subsection{Limbah Rumah Sakit}

Limbah rumah sakit adalah semua limbah yang dihasilkan dari kegiatan Rumah Sakit dalam bentuk padat, cair, pasta (gel) maupun gas yang dapat mengandung mikroorganisme pathogen bersifat infeksius, bahan kimia beracun, dan sebagian bersifat radioaktif. (Depkes, 2006) Limbah yang dihasilkan RSUD H. M. Djafar Harun Kabupaten Kolaka Utara meliputi:

a. Limbah Padat

Limbah padat rumah sakit adalah semua limbah rumah sakit yang berbentuk padat akibat kegiatan rumah sakit yang terdiri dari limbah medis dan non medis. (Keputusan MenKes R.I. No.1204 / MENKES / SK / X / 2004) Limbah padat yang dihasilkan oleh rumah sakit terdiri atas limbah padat B3 (Bahan Berbahaya dan Beracun), yang terbagi lagi menjadi limbah medis dan non medis, dan limbah domestik.

1) Limbah Medis, terdiri dari :

a) Limbah infeksius dan limbah patologi. Penyimpanan pada tempat sampah berplastik kuning.

b) Limbah farmasi (obat kadaluarsa). Penyimpanan pada tempat sampah berplastik coklat.

c) Limbah sitotoksis adalalah limbah yang berasal dari sisa obat pekayanan kemoterapi. Penyimpanan pada tempat sampah berplastik ungu.

d) Limbah medis padat tajam. Seperti pecahan gelas, jarum suntik, pipet dan alat medis lainnya. Penyimpanan pada safety box/ container.

e) Limbah radioaktif adalah limbah berasal dari penggunaan medis ataupun riset di labolatorium yang berkaitan dengan zat-zat 
radioaktif. Penyimpanan pada tempat sampah berplastik merah.

f) Limbah Non Medis. Limbah padat non medis yang dihasilkan rumah sakit meliputi aki, oli, dan lampu.

2) Limbah Domestik. Limbah domestik yang dihasilkan rumah sakit berupa sampah-sampah organik dan anorganik, seperti sisa-sisa makanan, plastik, kertas, dan lain-lain.

a) Limbah Cair. Limbah cair Rumah Sakit adalah semua air buangan termasuk tinja yang berasal dari kegiatan RS, yang kemungkinan mengandung mikroorganisme bahan beracun, dan radio aktif serta darah yang berbahaya bagi kesehatan. (Depkes RI, 2006) Limbah cair yang dihasilkan rumah sakit meliputi seluruh buangan cair yang berasal dari hasil proses seluruh kegiatan rumah sakit, yang sebagian besar meliputi limbah cair domestik, yakni buangan kamar dari rumah sakit.

\subsection{Penanganan Limbah}

\section{a. Limbah Padat}

Penangangan limbah padat yang dilakukan rumah sakit sudah mengikuti dan sesuai dengan prosedur Kemenkes RI No.1204/MENKES/SK/X/2004. Adapun penangan limbah padat yang dilakukan oleh rumah sakit adalah sebagai berikut:

\section{1) Pengumpulan}

a) Pemilahan limbah harus dilakukan mulai dari sumber yang menghasilkan limbah.

b) Limbah harus dipisahkan sesuai dengan jenisnya (medis, non medis, dan domestik). Untuk limbah B3 medis dipisahkan dengan menggunakan plastik warna sesuai jenis limbah tersebut.

c) Pengumpulan limbah B3 medis dari setiap ruangan penghasil limbah menggunakan troli khusus yang tertutup.

2) Penimbangan. Setelah limbah padat selesai dikumpulkan sesuai dengan jenisnya, kemudian dilakukan penimbangan dan pencatatan sebelum limbah padat tersebut disimpan.

3) Penyimpanan

a) Limbah B3 medis, B3 non medis, dan domestik disimpan ditempat terpisah.

b) Penyimpanan limbah B3 medis harus sesuai iklim tropis yaitu pada musim hujan paling lama 48 jam dan musim kemarau paling lama 24 jam.

4) Pembakaran. RSUD H. M. Djafar Harun Kabupaten Kolaka Utara memiliki incinerator namun terjadi kerusakan. Sehingga dalam pembakaran limbah padat pihak rumah sakit berkerjasama dengan pihak ketiga, yaitu untuk pengangkutan dan pembakaran limbah padat B3 medis dan B3 non medis, sementara untuk limbah padat domestik dilakukan kerjasama dengan warga sekitar.

\section{b. Limbah Cair}

Pengolahan limbah cair dilakukan dengan menggunakan IPAL (Instalasi Pengolahan Air Limbah) yang dalam hal ini RSUD H. M. Djafar Harun Kabupaten Kolaka Utara menggunakan pemanfaatan lumpur aktif (activated sludge). Lumpur aktif (activated sludge) adalah proses pertumbuhan mikroba tersuspensi. Proses ini pada dasarnya merupakan pengolahan aerobik yang mengoksidasi material organik menjadi $\mathrm{CO} 2$ dah $\mathrm{H} 2 \mathrm{O}$, 
Invoice: Jurnal Ilmu Akuntansi

p-ISSN: 2714-6359 e-ISSN: 2714-6340

Vol.2 Nomor 2 September 2020

NH4 dan sel biomassa baru. Proses ini menggunakan udara yang disalurkan melalui pompa blower (diffused) atau melalui aerasi mekanik. Sel mikroba membentuk flok yang akan mengendap di tangki penjernihan. Proses pengolahan limbah cair dengan menggunakan lumpur aktif (activated sludge) dapat dilihat pada gambar 4.1 dibawah ini:

\section{Gambar 2}

Sistem Pengolahan Air Limbah dengan Proses Lumpur Aktif

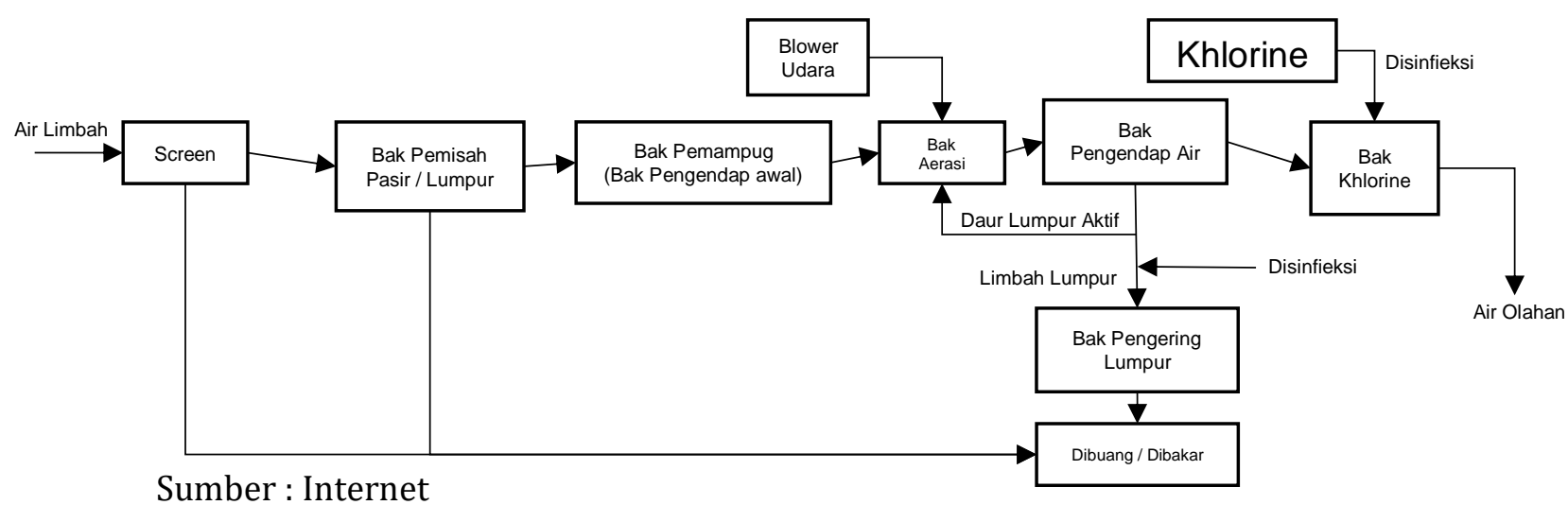

Gambar tersebut dapat dijelaskan bahwa tahap-tahap proses pengolahan limbah dengan menggunakan lumpur aktif adalah sebagai berikut:

1) Bak Pemisah Pasir

Air limbah dialirkan dengan tenang ke dalam bak pemisah pasir, sehingga kotoran yang berupa pasir atau lumpur kasar dapat diendapkan. Sedangkan kotoran yang mengambang misalnya sampah, plastik, sampah kain dan lainnya tertahan pada sarangan (screen) yang dipasang pada inlet kolam pemisah pasir tersebut.

2) Bak Pengendap Awal

Dari bak pemisah/pengendap pasir, air limbah dialirkan ke bak pengedap awal. Di dalam bak pengendap awal ini lumpur atau padatan tersuspensi sebagian besar mengendap. Waktu tinggal di dalam bak pengedap awal adalah 2 - 4 jam, dan lumpur yang telah mengendap dikumpulkan daan dipompa ke bak pengendapan lumpur.

3) Bak Aerasi

Pada bak aerasi oksigen ditambahkan ke dalam air limbah yang sudah dicampur lumpur aktif untuk pertumbuhan dan berkembang biak mikroorganisme dalam lumpur. Dengan agitasi yang baik, mikroorganisme dapat melakukan kontak dengan materi organik dan anorganik kemudian diuraikan menjadi senyawa yang mudah menguap seperti H2S dan NH3 sehingga mengurangi bau air limbah.

4) Bak Pengendap Akhir

Lumpur aktif akan mengendap kemudian dimasukkan ke tangki aerasi, sisanya dibuang. Lumpur yang mengendap inilah yang disebut lumpur bulki. Air limpasan (over flow) dari bak pengendap akhir relaitif sudah jernih, selanjutnya dialirkan ke bak khlorinasi. Sedangkan lumpur yang mengendap di dasar bak di pompa ke bak pemekat lumpur bersama-sama dengan lumpur yang berasal dari bak pengendap awal. 
Invoice: Jurnal Ilmu Akuntansi

p-ISSN: 2714-6359 e-ISSN: 2714-6340

Vol.2 Nomor 2 September 2020

5) Bak Khlorinasi

Air olahan atau air limpasan dari bak pengendap akhir masih mengandung bakteri coli, bakteri patogen, atau virus yang sangat berpotensi menginfeksi ke masyarakat sekitarnya. Untuk mengatasi hal tersebut, air limbah yang keluar dari bak pengendap akhir dialirkan ke bak khlorinasi untuk membunuh mikroorganisme patogen yang ada dalam air. Di dalam bak khlorinasi, air limbah dibubuhi dengan senyawa khlorine dengan dosis dan waktu kontak tertentu sehingga seluruh mikro-orgnisme patogennya dapat di matikan. Selanjutnya dari bak khlorinasi air limbah sudah boleh dibuang ke badan air.

\section{6) Bak Pengering Lumpur}

Surplus dari bak pengendap awal maupun bak pengendap akhir ditampung dalam bak pengering umpur, sedangkan air resapannya ditampung kembali di bak penampung air limbah. Setelah melalui pengolahan air limbah rumah sakit dengan proses lumpur aktif tersebut, air limbah rumah sakit dapat dibuang ke lingkungan dengan aman. Artinya limbah rumah sakit tidak lagi membahayakan bagi lingkungan sekitar.

\subsection{Pembahasan}

Pelaporan biaya lingkungan merupakan komponen dari laporan keuangan lingkungan. Laporan keuagan lingkungan pada suatu periode tertentu selain terdapat keuntungan: pemasukan, penghematan saat ini serta penghematan berjalan juga terdapat berbagai komponen biaya biaya lingkungan yang dikeluarkan oleh Rumah Sakit yang kegiatan operasionalnya menghasilkan limbah. (Nurfadillah, 2016)
Pelaporan suatu biaya lingkungan termasuk penting karena merupakan suatu bentuk transparasi yang dilakukan oleh suatu Rumah Sakit. Dengan melaporkan biaya lingkungan juga dapat menunjukkan keseriusan dan kepeduliah suatu Rumah Sakit terhadap lingkungan. Pelaporan biaya lingkungan juga dapat memotivasi suatu Rumah Sakit dalam peningatan kinerja lingkungannya dan dapat membantu pihak manajerial mengetahui aktivitas apa saja yang sudah dilakukan dalam upaya menjaga kelestarian lingkungan. Selain itu pelaporan biaya lingkungan juga dapat membantu suatu Rumah Sakit dalam mengendalikan pengeluaran biaya lingkungan.

RSUD H. M. Djafar Harun Kabupaten Kolaka Utara dalam menyajikan pelaporan biaya lingkungan. Penulis mengaplikasikan teori Hansen dan Mowen dalam pelaporan biaya lingkungan, yang sebagian besar pelaporan biaya lingkungan yang digunakan oleh suatu Rumah Sakit ialah menggunakan teori Hansen dan Mowen tersebut. Pengklasifikasian biaya lingkungan menurut Hansen dan Mowen terbagi menjadi empat kategori:

1. Biaya Pencegahan Lingkungan (environmental prevention costs), yaitu biaya - biaya untuk aktifitas yang dilakukan untuk mencegah diproduksinya limbah dan/ atau sampah yang dapat merusak lingkungan. Contoh aktivitas secara umum dalam pencegahan pada RSUD H. M. Djafar Harun Kabupaten Kolaka Utara yaitu biaya gaji pengelola lingkungan dan IPAL, biaya pemeliharaan IPAL, biaya pembasmian serangga dan binatang pengganggu, biaya kebersihan. 
Invoice: Jurnal Ilmu Akuntansi

p-ISSN: 2714-6359 e-ISSN: 2714-6340

Vol.2 Nomor 2 September 2020

2. Biaya Deteksi Lingkungan (environmental detection cost), adalah biaya - biaya untuk aktifitas yang dilakukan untuk menentukan bahwa produk, proses, dan aktifitas, lain di Rumah Sakit telah memenuhi standar lingkungan yang berlaku atau tidak. Contoh aktivitas secara umum dalam deteksi pada RSUD H. M. Djafar Harun Kabupaten Kolaka Utara yaitu biaya uji limbah cair, biaya lab air bersih, dan biaya lab mikrobiologi.

3. Biaya Kegagalan Internal Lingkungan (environmental internal failure cost), adalah biaya - biaya untuk aktifitas yang dilakukan karena diproduksinya limbah dan sampah, tetapi tidak dibuang ke lingkungan luar Contoh aktivitas secara umum dalam kegagalan internal pada RSUD H. M. Djafar Harun Kabupaten Kolaka Utara yaitu biaya transportasi sampah medis dan non medis, biaya bakar sampah medis, biaya retribusi sampah domestik, biaya semprot saluran dan biaya sedot wc.

4. Biaya Kegagalan Eksternal Lingkungan (environmental external failure), adalah biaya - biaya untuk aktifitas yang dilakukan setelah melepas limbah atau sampah ke dalam lingkungan. Biaya kegagalan eksternal lingkungan juga dapat dibagi menjadi dua yaitu :

a. Biaya kegagalan eksternal yang dapat direalisasi adalah biaya yang dialami dan dibayar oleh Rumah Sakit.

b. Biaya kegagalan eksternal yang tidak direalisasikan atau biaya social disebabkan oleh Rumah
Sakit, tetapi dialami dan dibayar oleh pihak-pihak diluar Rumah Sakit Pada biaya kegagalan eksternal Rumah Sakit belum pernah mengeluarkan biaya.

Penulis memperoleh data biaya lingkungan (biaya aktivitas sanitasi lingkungan) secara rinci dalam buku besar biaya yang dimiliki oleh rumah sakit. Buku besar biaya ini adalah kumpulan dari biaya-biaya yang dikeluarkan oleh rumah sakit secara menyeluruh. Biaya lingkungan (biaya aktivitas sanitasi lingkungan) pada rumah sakit tersaji bersamaan dengan biaya-biaya lain dalam rekening Biaya Pemeliharaan SAPRAS (Sarana Pra Sarana). Penulis mengambil data biaya lingkungan pada tahun 2019. Sedangkan untuk informasi data biaya gaji pengelola lingkungan dan IPAL diperoleh penulis melalui wawancara dengan bagian pengawasan dan pengendalian, karena dalam buku besar biaya, biaya gaji hanya tersaji dengan keterangan nomor rekening, sehingga menyulitkan penulis dalam mengetahui besarnya jumlah gaji tersebut. Dalam wawancara tersebut, Bapak TM selaku bagian penunjang dan pelayanan kesehatan, menyebutkan bahwa:

"Untuk pengelola lingkungan dan IPAL gaji yang dikeluarkan sebesar $R p$ 50.000.000 untuk dua pegawai dalam setahun".

Berikut adalah alternatif biaya lingkungan RSUD H. M. Djafar Harun Kabupaten Kolaka Utara pada tahun 2019: 
Invoice: Jurnal Ilmu Akuntansi

p-ISSN: 2714-6359 e-ISSN: 2714-6340

Vol.2 Nomor 2 September 2020

Tabel 3 Alternatif Laporan Biaya Lingkungan tahun 2019

\begin{tabular}{|c|c|c|c|}
\hline Keterangan & \multicolumn{2}{|c|}{ Biaya Lingkungan } & $\%$ dari total biaya \\
\hline \multicolumn{4}{|l|}{ Biaya Pencegahan : } \\
\hline $\begin{array}{l}\text { Biaya Gaji Pengelola Lingkungan \& } \\
\text { IPAL }\end{array}$ & $50,000,000$ & & \\
\hline Biaya Spoll Blower & 250,000 & & \\
\hline Biaya Servis Pompa Limbah & 100,000 & & \\
\hline Biaya Cleanning Service & $25,200,000$ & & \\
\hline Biaya Obat Nyamuk & 20,000 & & \\
\hline Biaya Racun Tikus & 51,000 & $75,621,000$ & $1.91 \%$ \\
\hline \multicolumn{4}{|l|}{ Biaya Deteksi : } \\
\hline Biaya Uji Limbah Cair & $2,402,000$ & & \\
\hline Biaya Uji Lab. Air Bersih & 340,000 & & \\
\hline Biaya Uji Lab. Mikrobiologi & $1,328,500$ & $4,070,500$ & $0.10 \%$ \\
\hline \multicolumn{4}{|l|}{ Biaya Kegagalan Internal : } \\
\hline Biaya Transportasi Sampah Medis & $5,047,000$ & & \\
\hline $\begin{array}{l}\text { Biaya Transportasi Sampah Non } \\
\text { Medis }\end{array}$ & 100,000 & & \\
\hline Biaya Retribusi Sampah Domestik & 150,000 & & \\
\hline Biaya Bakar Sampah Medis & $5,481,700$ & & \\
\hline Biaya Semprot Saluran & 425,000 & & \\
\hline Biaya Sedot WC & 500,000 & $11,703,700$ & $0.30 \%$ \\
\hline Biaya Kegagalan Eksternal : & \multicolumn{2}{|c|}{. } & - \\
\hline Total Biaya Lingkungan & \multicolumn{2}{|r|}{$91,395,200$} & $2.31 \%$ \\
\hline Total Biaya Operasional & \multicolumn{2}{|c|}{$3,950,000,000$} & $100 \%$ \\
\hline
\end{tabular}

Sumber: RSUD H. M. Djafar Harun Kabupaten Kolaka Utara

$$
\text { Alternatif laporan biaya }
$$

lingkungan tersebut dapat dilihat bahwa rumah sakit tidak mengeluarkan biaya kegagalan eksternal. Dengan ini dapat disimpulkan bahwa rumah sakit sudah melakukan pengelolaan lingkungan dengan baik sehingga dampak buruk yang dihasilkan dari aktivitas rumah sakit tidak mengganggu dan merugikan lingkungan luar atau masyarakat sekitar. Dengan kata lain pencegahan serta pengendalian terhadap lingkungan sudah dilakukan dengan baik oleh pihak rumah sakit. Dari pembahasan yang diuraikan, berdasarkan permasalahan dan tujuan penelitian yang akan dicapai maka dapat ditarik hasil penelitian sebagai berikut:
1. Biaya lingkungan yang dikeluarkan oleh RSUD H. M. Djafar Harun Kabupaten Kolaka Utara teridentifikasi dalam aktivitas yang dilakukan dalam sanitasi lingkungan rumah sakit, yaitu : Aktivitas pengelolaan limbah cair, biaya yang dihasilkan secara umum berupa Biaya Gaji Pengelola Lingkungan dan IPAL, Biaya Pemeliharaan IPAL, Biaya Pengujian Limbah, Biaya Sedot WC, Biaya Semprot Saluran. Aktivitas pengelolaan limbah padat, biaya yang dihasilkan secara umum berupa Biaya Transportasi, Biaya Pembakaran, Biaya Retribusi Sampah Domestik, Biaya Kebersihan. Aktivitas Penyehatan Air Bersih, biaya yang dihasilkan secara umum berupa 
Invoice: Jurnal Ilmu Akuntansi

p-ISSN: 2714-6359 e-ISSN: 2714-6340

Vol.2 Nomor 2 September 2020

Biaya Uji Air Bersih. Aktivitas Pengendalian Vektor \& Binatang pengganggu, biaya yang dihasilkan secara umum berupa Biaya Pembasmian Serangga dan Binatang Pengganggu Pengidentifikasian biaya lingkungan yang dilakukan rumah sakit belum sesuai dengan teori Hansen dan Mowen karena hanya diakui sebagai Biaya SAPRAS (Sarana Prasarana) dan Biaya Gaji \& Upah.

2. RSUD H. M. Djafar Harun Kabupaten Kolaka Utara mengakui biaya lingkungan pada saat terjadinya transaksi kas keluar. Biaya lingkungan yang diakui oleh RSUD H. M. Djafar Harun Kabupaten Kolaka Utara sesuai dengan definisi unsur yang harus diakui pada Kerangka Dasar Penyusunan Penyajian Laporan Keuangan (KDPPLK) paragraf 83 tahun 2015.

3. RSUD H. M. Djafar Harun Kabupaten Kolaka Utara mengukur biaya lingkungan sesuai dengan Kerangka Dasar Penyusunan Penyajian Laporan
Keuangan (KDPPLK) paragraf 100, yaitu menggunakan pengukuran biaya historis, dengan satuan moneter rupiah sesuai dengan cost yang dikeluarkan.

4. RSUD H. M. Djafar Harun Kabupaten Kolaka Utara belum menyajikan biaya lingkungan secara eksplisit atau belum menyajikan terpisah dengan laporan iduk. Biaya lingkungan disajikan pada laporan laba rugi sebagai sub Biaya Pelayanan Pasien dan sub Biaya Administrasi \& Umum. Penyajian biaya lingkungan cenderung mengikuti model normatif.

5. RSUD H. M. Djafar Harun Kabupaten Kolaka Utara belum mengungkapkan biaya lingkungan pada catatan atas laporan keuangan, namun tetap mengungkapkan biaya lingkungan.

Berdasarkan penjelasan tersebut, diperoleh juga laporan CSR pada rumah sakit yang dapat dijelaskan pada tabel dibawah ini:

Tabel 4 Laporan CSR RSUD H. M. Djafar Harun tahun 2019

\begin{tabular}{|c|c|c|}
\hline No & Perihal & $\begin{array}{l}\text { Realisasi Pembiayaan } \text { Disalurkan } \\
\text { (Rp) }\end{array}$ \\
\hline 1 & $\begin{array}{l}\text { Workshop Peningkatan Mutu dan } \\
\text { Keselamatan Pasien }\end{array}$ & \multirow{3}{*}{ Rp. $288,300,000$} \\
\hline 2 & $\begin{array}{l}\text { Workshop Pencegahan dan } \\
\text { Pengendalian Infeksi }\end{array}$ & \\
\hline 3 & $\begin{array}{l}\text { Workshop Pelayanan Kefarmasian dan } \\
\text { Penggunaan Obat }\end{array}$ & \\
\hline
\end{tabular}

Sumber: CSR RSUD H. M. Djafar Harun 
Invoice: Jurnal Ilmu Akuntansi

p-ISSN: 2714-6359 e-ISSN: 2714-6340

Vol.2 Nomor 2 Agustus 2020

Berdasarkan penjelasan tersebut, dapat diartikan bahwa rumah sakit telah melakukan CSR tersebut dengan bertujuan untuk meningkatkan kualitas pelayanan kesehatan sehingga jumlah kunjungan dan penggunaan tempat tidur di RSUD H. M. Djafar Harun Kabupaten Kolaka Utara meningkat. Adapun pokokpokok kegiatannya adalah Pemeliharaan dan pemulihan kesehatan.

Hasil penelitian yang membahas tentang akuntansi lingkungan ini telah sesuai dengan legitimacy theory menurut Wardani dan Januarti (2013) menjelaskan bagaimana kepekaan perusahaan agar dapat bertanggungjawab terhadap lingkungannya. Berdirinya perusahaan tidak terlepas dari dukungan masyarakat, oleh karena itu harus memperhatikan kepentingan masyarakat. Untuk menjalankan operasional perusahaan, maka mengacu pada kontrak sosial (social contract) mencakup hak dan kewajiban dan menyesuaikan dengan kondisi masyarakat. Kontrak sosial menjadi media dalam pencapaian tujuan perusahaan yang diiringi dengan tanggung jawab terhadap masyarakat. Berdasarkan penjelasan tersebut, telah terbukti dengan melakukan penerapan akuntansi lingkungan dan CSR maka dapat diartikan bahwa rumah sakit telah bertanggungjawab terhadap lingkungan sekitar.

Penelitian ini berfokus pada indikator triple bottom line khusus aspek lingkungan, ekonomi, sosial yang tidak bisa dipisahkan sebagaimana dikemukan oleh John Elkington dalam Lako (2011: 65) bahwa agar bisnis Rumah Sakit bisa tumbuh secara berkelanjutan hanya ada satu pilihan, yaitu menyeleraskan pencapaian kinerja laba (profit) dengan kinerja sosial (people) dan kinerja lingkungan (planet) secara berkesinambungan.

Pada implementasi lingkungan (Planet), RSUD H. M. Djafar Harun Kabupaten Kolaka Utara telah menggunakan pengukuran aturan Kerangka Dasar Penyusunan Penyajian Laporan Keuangan (KDPPLK), program renja 2019 yang fokus terhadap lingkungan, dan pelaksanaan yang menggunakan uji laboratorium terhadap barang medis dan non medis, maka dapat disimpulkan RSUD H. M. Djafar Harun Kabupaten Kolaka Utara telah melakukan implementasi akuntansi lingkungan berdasarkan triple bottom line berdasarakan aspek lingkungan.

Hasil penelitian ini sejalan dengan pendapat Syuhada (2012:27) yang mengatakan Planet atau Lingkungan adalah sesuatu yang terkait dengan seluruh bidang dalam kehidupan manusia. Hubungan Rumah Sakit dengan lingkungan adalah hubungan sebab akibat, dimana jika Rumah Sakit merawat lingkungan maka lingkungan akan memberikan manfaat kepada Rumah Sakit. Sudah kewajiban Rumah Sakit untuk peduli terhadap lingkungan hidup dan berkelanjutan keragaman hayati. Misalnya, penghijauan lingkungan hidup, perbaikan pemukiman, serta pengembangan pariwisata (ekoturisme).

Pada aspek masyarakat (People) ini, RSUD H. M. Djafar Harun selalu berusaha menyediakan APD kepada masyarakat sekitar dengan selalu memperhatikan stok yang tersedia dan menghimpun bantuan dari komunitas daerah serta seminar yang dilakukan oleh RSUD H. M. Djafar Harun membahas mengenai perubahan perilaku yang 
Invoice: Jurnal Ilmu Akuntansi

p-ISSN: 2714-6359 e-ISSN: 2714-6340

Vol.2 Nomor 2 Agustus 2020

seharusnya dilakukan pada saat pandemi serta menjaga dan meningkatkan kesehatan agar dapat mencapai derajat kesehatan yang optimal. Hal ini dilakukan untuk memberikan pengetahuan kepada masyarakat agar dapat menjaga diri apabila kondisi pandemi semakin memburuk. Berdasarkan penjelasan tersebut, RSUD H. M. Djafar Harun telah melakukan implementasi akuntansi lingkungan berdasarkan triple bottom line berdasarkan aspek masyarakat.

Hasil penelitian tersebut, sejalan dengan teori menurut Wibisono, (2007) dalam Aryani dan Amanah, (2014) perusahaan dituntut untuk memiliki kepedulian terhadap manusia. Hal tersebut berkaitan dengan praktikpraktik bisnis yang adil dan menguntungkan terhadap pekerja dan masyarakat dan daerah di mana sebuah perusahaan menjalankan bisnisnya.

Pada aspek ekonomi (Profit), RSUD H. M. Djafar Harun telah melakukan berdasarkan program rejan 2019 yaitu dengan mejaga sarana dan prasarana serta menekan pengangguran dan memberikan pengalaman kepada tenaga kesahatan yang dapat membuat kinerja rumah sakit meningkat sehingga dapat meningkatkan profit pada rumah sakit, maka dapat dikatakan RSUD H. M. Djafar Harun Kabupaten Kolaka Utara telah melakukan Implementasi akuntansi lingkungan berdasarkan triple bottom line berdasarkan aspek ekonomi.

Hasil penelitian tersebut, telah sesuai dengan teori menurut Wibisono, (2007) dalam Aryani dan Amanah, (2014) yang mengatakan bahwa untuk dapat meningkatkan pencapaian keuntungan dalam sebuah perusahaan yaitu dengan cara meningkatkan produktivitas.

\section{PENUTUP}

\subsection{Simpulan}

Penelitian ini bertujuan untuk mengetahui implementasi akuntansi lingkungan yang ditinjau dari teori Triple Bottom Line sebagaimana yang diungkapkan oleh John Elkington bahwa Triple Bottom Linetidak hanya melihat aspek profit (keuntungan) sebagai acuan utama dalam aktivitas Rumah Sakit. Berdasarkan hasil penelitian yang dilakukan oleh peneliti dengan menggunakan indikator-indikator yang ada, maka hasil penelitian ini adalah:

1. Kegiatan-kegiatan CSR yang dilaksanakan oleh RSUD H. M. Djafar Harun Kabupaten Kolaka Utara secara umum telah memenuhi teori atau konsep triple bottom line yang mencakup pada tiga unsur utama yaitu, profit, people dan planet serta aspek keberlanjutan program yang dinilai. Prinsip pembangunan keberlanjutan yang menyebutkan bahwa manusia dan lingkungan bagian yang integral sebuah roda perputaran bisnis Rumah Sakit.

2. Tanggung jawab ekonomi (profit) dapat dilihat pada produk-produk kesehatan RSUD H. M. Djafar Harun Kabupaten Kolaka yang dihasilkan dari kegiatan pelayanan kesehatan lainnya.

3. Tanggung jawab lingkungan (planet) dapat dilihat dari program-program CSR bidang lingkungan secara nyata dilakukan untuk menyelamatkan dan melestarikan lingkungan seperti penanaman pohon dan tempat pembuangan limbah kegiatan RSUD $\mathrm{H}$. M. Djafar Harun Kabupaten Kolaka. 
4. Tanggung jawab sosial (people) secara nyata dilaksanakan melalui aktivitas CSR pada bantuan sarana kesehatan.

\subsection{Saran}

Saran yang dapat diberikan penulis kepada RSUD H. M. Djafar Harun Kabupaten Kolaka Utara dan peneliti selanjutnya adalah sebagai berikut:

1. Peneliti selanjutnya diharapkan bisa menemukan standar pengukuran biaya lingkungan sehingga bisa diperbandingkan dengan kondisi di suatu rumah sakit.

2. Peneliti selanjutnya diharapkan meneliti biaya lingkungan pada Rumah Sakit/entitas jasa yang terkait langsung dengan lingkungan.

3. RSUD H. M. Djafar Harun Kabupaten Kolaka Utara sebaiknya menyajikan biaya lingkungan secara terpisah atau eksplisit dari laporan keuangan induk atau mengungkapkan biaya lingkungan pada catatan atas laporan keuangan, agar pengguna laporan dapat mudah mengetahui biaya lingkungan yang terdapat di rumah sakit. RSUD H. M. Djafar Harun Kabupaten Kolaka Utara sebaiknya membuat anggaran tahunan terkait dengan biaya lingkungan, agar proses pengukuran dan pengakuan jauh lebih terstruktur.

4. RSUD H. M. Djafar Harun Kabupaten Kolaka Utara sebaiknya melakukan penyusutan terhadap IPAL sehingga dapat mengetahui besarnya biaya penyusutan pada IPAL.

\section{DAFTAR PUSTAKA}

Adam, C.A. dan P. McNicholas. 2007. Making a Difference: Sustainability Reporting, Accountability and Organizational Change". Accounting, Auditing \&
Accountability Journal. 20(3): 382 402.

Aminah dan Noviani. 2014. Analisis Penerapan Akuntansi Lingkungan Di Rumah Sakit Mardi Waluyo Metro.Jurnal Akuntansi \& Keuangan. 5 (2):1-16.

Andranovich, G dan G. Riposa. 1993. Doing Urban Reaserch. Newbury Park: Sage Publications.

Aryani, D. D dan L. Amanah. 2014. Analisis Pengungkapan Corporate Social Responsibility Terhadap Kinerja Keuangan. Jurnal IImu Dan Riset Akuntansi. 3(2): 1-15.

Astuti, N. 2012. Mengenal Green Accounting. Permana. 4(1): 69-75.

Aulya. R., A. Sunaryo dan W. Y. Prasetyo. 2017. Implementasi Program Corporate Social Responsibility Dalam Mewujudkan Sustainable Development Di Bidang Lingkungan. Jurnal Administrasi Publik. 2(4): 608-612.

Burhany, I. D dan Nurniah. 2014. Akuntansi Manajemen Lingkungan Sebagai Alat Bantu Untuk Meningkatkan Kinerja Lingkungan Dalam Pembangunan Berkelanjutan. SNA 17 Mataram. 125.

Burhany, I. D. 2014. Pengaruh Implementasi Akuntansi Lingkungan Terhadap Kinerja Lingkungan Dan Pengungkapan Informasi Lingkungan. Proceeding SNEB. 1-8.

Cohen, N., dan P. Robbins .2011.Green Business: An A-to-Z Guide, Thousand Oaks, California: SAGE Publications Inc.

Deegan, C, 2003. Environmental Management Accounting: An Introduction and Case Studies for Australia, Environment Australia, Environment protection Authority, 
Victoria, Institute of Chartered Accountants Australia.

Deegan, C. 2002. Introduction Accounting, Auditing \& Accountability Journal. 15(3): 282311.

Dewi, S. R. 2016. Pemahaman Dan Kepedulian Penerapan Green Accounting: Studi Kasus Ukm Tahu Di Sidoarjo.Prosiding Seminar Nasional Ekonomi dan Bisnis and Call For Paper FEB UMSIDA: 497511.

Dowling, J. dan J. Pfeffer. 1975. "Organizational Legitimacy: Social Values and Organizational Behaviour". Pacific Sociology Review. 18(1): 122- 136.

Elkington, J. 1998. Accounting For The Triple Bottom Line. Measuring Business Excellence, 2(3): 18-22.

Felisia, Amelia Limijaya. 2014. Triple Bottom Line Dan Sustainability. Volume 14 18, Nomor 1, Januari 2014.

Freeman, E. 2002. Stakeholder Theory Of The Modern Corporation. General Issues in Businness Ethics. 38-48.

Ghozali dan Chariri. 2007. Teori Akuntansi. Semarang: Badan Penerbit Undip.

Gray, R. 2006. Social, Environmental and Sustainability Reporting and Organisation Value Creation? Whose Value? Whose Creation? Accounting, Auditing and Accountability Journal. 19 (6): 793 819.

Hanifah, U. 2013. Aktualisasi Carbon Emission Disclosure: Sebagai Dasar Dan Arah Pengembangan Triple Bottom Line. Seminar Nasional dan The 3rd Call For Syariah Paper. 125-135.

http://repository.unpas.ac.id/354 77/5/BAB\%20II.pdf (11 Februari 2020).
Hasyim. "Akuntansi Lingkungan: Apakah sebuah pilihan atau kewajiban". Jurnal. 2011.

Heriyani, Emrinaldi Nur DP dan Alfiati Silfi. 2019. Analisis Pengungkapan Triple Bottom Line Dan Faktor Yang Mempengaruhi: Studi Di Perusahaan Indonesia Dan Singapura. Jurnal Akuntansi, Vol. 8, No. 1, Oktober 2019: 67 - 79.

I Gusti Bagus Ngurah Panji Putra* dan Gde Deny Larasdiputra. 2020. Penerapan Konsep Triple Bottom Line Accounting Di Desa Wisata Pelaga (Studi Kasus Pada Kelompok Usaha Tani Asparagus). Jurnal KRISNA: Kumpulan Riset Akuntansi; Vol. 11, No. 2 Januari 2020, pp. 129-136. ISSN: 2301-8879. E-ISSN: 2599-1809

Ikhsan, Arfan. 2008. Akuntansi Lingkungan dan Pengungkapannya. Yogyakarta: Graha Ilmu.

Inilahsultra.com (2019). 12 Rumah Sakit di Sultra Turun Kelas. https://inilahsultra.com/2019/07 /29/12-rumah-sakit-di-sultraturun-kelas/. Diakses pada Juli 2020.

Ismie Dzakky Fatimah. 2011. Penerapan Akuntansi Lingkungan (Studi Kasus Pada PT Semen Indonesia (Persero) Tbk Tuban). Koran Kompas 27 Maret 2011.

Januarti, I. dan D. Apriyanti. 2005. Pengaruh Tanggung Jawab Social Perusahaan Terhadap Kinerja Keuangan. Jurnal Maksi, 5(2): 227243.

Lindrianasari. 2007. Hubungan antara Kinerja Lingkungan dan Kualitas Pengungkapan dengan Kinerja Ekonomi Perusahaan di Indonesia. Jurnal Akuntansi dan Auditing Indonesia. 11 (2):159-172.

Lako Andreas. Dekonstruksi CSR dan Reformasi Paradigma Bisnis dan 
Invoice: Jurnal Ilmu Akuntansi

p-ISSN: 2714-6359 e-ISSN: 2714-6340

Vol.2 Nomor 2 Agustus 2020

Akuntansi. Jakarta: Penerbit Erlangga. 2011.

Martusa Riki. "Peranan Environmental Accounting Terhadap Global Warming". Jurnal Akuntansi Vol.1 No.2 November 2009:164-179.

Manuhara, Wahyu. 2000. Audit Lingkungan: Pengungkapan Isu Lingkungan Dalam Laporan Keuangan Auditan.Jurnal Akuntansi dan Investasi. 1 (2):

Musyarofah, S. 2013. Analisis Penerapan Green Accounting Dikota Semarang. Accounting Analysis Journal. 2(3): 352-359.

Muqodim. 2013. Triple Bottom Line Reporting Dalam Pelaporan Tahunan Perusahaan Go Public Di Indonesia. JAAI Vol. 17 No. 1, Juni 2013: 13-42.

Niar,I. dan F. Yeni.2012.Penerapan Green Accounting BAgi Rumah Sakit Sektor Publik Dalam Rangka Mendukung Peran Akuntansi Manajemen.Sekolah tinggi akuntansi Negara.

Nugroho, K. A dan A. Purwanto. 2013. Pengaruh Karakteristik Perusahaan, Struktur Kepemilikan, Dan Good Corparate Governance Terhadap Pengungkapan.

Nuryanti, Dewi. "Pengertian Data Kualitatif dan Kuantitatif". (http://www.dewinuryanti.com/2 012/12/datakualitatifpengertiand aakualitatif- kuantitatif.html. (3 Februari 2020).

Onyali dan C. Innocent. 2014. Triple Bottom Line Accounting And Sustainable Corporate Performance. Reasearch Journal of Finance and Accounting. 5(8):195210.

Peraturan Pemerintah Republik Indonesia Nomor 1 Tahun 2010 tentang Pernyataan Standar Akuntansi Pemerintah.
Rohelmy, F. A. 2015. Efektivitas Penerapan Biaya Lingkungan Dalam Upaya Meminimalkan Dampak Lingkungan. Jurnal Administrasi Bisnis (JAB). 2 (2):110.

Sanusi, Anwar. 2011. Metodologi Penelitian bisnis. Jakarta: Salemba empat. Sekaran, U. 2006. Research Methods For Business. Jakarta: Salemba Empat.

Shella Budiawan. 2019. Analisis Pengungkapan Triple Bottom Line Dalam Penerapan Akuntansi Manajemen Lingkungan Pada Industri Pertambangan. Gorontalo Accounting Journal (GAJ) Volume 2 Nomor 1 April 2019.

Siti Rachmi Harimisa, Grace B. Nangoi dan Treesje Runtu. 2018. Analisis Penerapan Akuntansi Manajemen Lingkungan Pada Ud. Santoso Di Manado. Jurnal Riset Akuntansi Going Concern 13(2), 2018, 300311.

Soelistyoningrum, Jenia Nur. "Pengaruh Pengungkapan Sustainability Report Terhadap Kinerja Keuangan (Studi Empiris Pada Perusahaan Yang Terdaftar Dalam Bursa Efek Indonesia)."

Suartana, I. W. 2015. Akuntansi Lingkungan dan Tripple Bottom Line Accounting: Paradigma Baru Akuntansi Bernilai Tambah. Jurnal Bumi Lestari, 10 (1): 105-112.

Susiana sari, Nengah Sudjana dan Devi Farah Azizah. 2013. Penerapan Akuntansi Lingkungan Untuk Mengoptimalkan Tanggung Jawab Industri Gula (Studi Pada PT Perkebunan Nusantara X Unit Pabrik Gula Lestari Nganjuk). Jurnal Administrasi Bisnis (JAB)|Vol. 2 No. 1 Mei 2013.

Sunyoto, D. 2013. Metode penelitian Akuntansi. Yogyakarta: PT Refika Aditama. 
Invoice: Jurnal Ilmu Akuntansi

$p$-ISSN: 2714-6359 e-ISSN: 2714-6340

Vol.2 Nomor 2 Agustus 2020

Tarigan, J dan H. Samuel. 2014. Pengungkapan Sustainability Report Dan Kinerja Keuangan. Jurnal Akuntansi Dan Keuangan. 16(2): 88-101.

Villiers, D. C dan V. Staden. 2006. Can Less Environmental Disclosure Have a Legitimising Effect? Evidence From Africa. Accounting Organizations And Society. 31(8): 763-781.

Yusuf, W. 2007.Membedah Konsep \& Aplikasi CSR (Corporate Social Responsibility).Jakarta. PT Gramedia.

Yusuf, Muri. 2014. Metode Penelitian: Kuantitatif, Kualitatif Dan Penelitian Gabungan. Kencana: Jakarta. 